\title{
A GARDEN OF SOUTH AFRICAN FLOWERS
}

K. C. STANFORD 


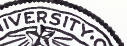

बั:

.

1888.

\section{THE LIBRARY}

OF

THE UNIVERSITY

OF CALIFORNIA

LOS ANGELES 
157

$\sim$ 



$$
\begin{gathered}
\text { A GARDEN } \\
\text { of } \\
\text { SOUTH AFRICAN } \\
\text { FLOWERS } \\
\text { By C. STANFORD }
\end{gathered}
$$

CAPE TOWN

MASKEW MILLER LIMITED 
哧

Printed by

CAPE TIMES LIMITED,

KEEROM STREET,

CAPE TOWN. 



\section{FOREWORD}

7 HESE flowers of the calendar tell their own tale throughout the weeks and months of the year, their "own inconIl scient happiness, each type a faultless essence of God's will"; and we are fortunate indeed to have so faithful and lively a record from one who has lived and moved among them for more than twenty years with a rare and persisting devotion to their needs, inspired by the simple yet all-important rule that to know about growing flowers one must grow them. And Miss Stanford has shown us how many and varied these can be, even within the restricted limits imposed upon her at Bloem Erf, the garden she has made to yield treasures for flower lovers in this and distant lands throughout the world.

There are delightful accounts of happy plant-hunting expeditions, with glimpses of the flowers in their natural haunts whence many were transplanted to join the company already established on that sunny bird-land slope at Banhoek. Their chief claim for admission has been, of course, that they should have some horticultural value. Miss Stanford, however, makes this claim elastic enough to embrace some of the humbler plants whose charm and possibilities she has recognized and developed, so that in skilful combination with their more handsome companions the beauty of all is enhanced.

But this is also a human document with its story of struggle against the ravages of tempest and torrent, drought and baking heat; and of joy in fragrant nights, flitting fireflies, halcyon days, sunset-glows, magic moonlight and healing dreams of the toil-worn, perhaps of

The island-valley of Avilion,

Where falls not hail, or rain, or any snow,

Nor ever wind blows loudly; but it lies

Deep meadow'd, happy, fair with orchard lawns

And bowery hollows crowned with summer sea.

L. BOLUS. 



\section{IN'TRODUG'TION}

There is a bond between the men who go

From youth about the business of the earth

And the earth they serve, their cradle and their grave;

Stars with their seasons alter; only be

Who wakeful follows the pricked revolving sky

Turns concordant with the earth while others sleep.

To bim the dawn is punctual; to bim

The quarters of the year no empty name.

V. SACKVille-IVest.

I $\mathrm{N}$ the first place, this book was written for my own satisfaction, for the joy of passing on to gardeners the world over the happiness I have had in growing these treasures from veld and mountain and stream-side. If these rambling notes have the power to stir one South African to grow and develop any of our wild flowers, the book will have achieved some measure of success. There are people now in every part of the country who are planting wild-flower gardens because they realize that (apart from the sheer beauty of the flowers themselves) they are so much more suited to our soil, climate and scenery. As to plantsmen in Europe, the United States of America, Australia and New Zealand, their cry has always been "Give us more seeds and more bulbs, and tell us how to grow them". I hope the book may be useful to them.

There are many omissions, I know ; but I have only written about plants that I have actually grown. There is no mention of the great family of the heaths, or of small succulents, or of the many herbaceous things that I might have grown and have not.

I should like to take this opportunity of thanking Dr. Bolus and the staff of the Bolus Herbarium, who for over twenty years 
have named specimens for me. Without their help my work would have been impossible. I can never be grateful enough to them.

Also I want to thank Mr. Mathews, who so generously passed on to me much of the knowledge he had gained as Curator of the National Botanic Gardens, Kirstenbosch, whose advice and encouragement has saved me many a failure, and who may still be relied on to admire hybrid Dimorphothecas for hours on end without a sign of exhaustion.

Thanks are due, too, to all those people up and down the country who out of the kindness of their hearts have sent me seeds, bulbs and plants. Perhaps they will find them again in this book. To Niss Edith Stephens, the genial Secretary of the Cape Natural History Society, whose left hand is certainly in complete ignorance of the good her right is doing, I tender my sincere thanks. And, lastly, to the most good-tempered of photographers, Mr. R. Nicholson, who would willingly expend his precious rationed petrol to come ten miles to make a picture of some elegant beauty, only to find a puffy wind blowing, and the fair one too coy to be caught by the camera.

There are many others whom I should like to thank; but they are kind-hearted and generous folk and will know that kindnesses received over so many years would, if listed, fill a volume.

And so the little book goes on its way. I hope it may give pleasure to plant-lovers in many countries. It has already many old friends waiting to receive it, and I hope that it will make many new ones for itself.

Bloem Erf,

K. C. Stanford.

Stellenbosch. 
THIS MORNING I woke to a new sound. For some time it remained in the subconscious stratum of my mind, though I was awake enough to know it to be something entirely good. Then it flashed into my waking consciousness- "The swallow twittering in the straw-built shed". The straw-built shed is now the telephone wire; but the voice of the swallow is the same and it evokes the same thrill. Curiously enough, about an hour later I heard the Piet-myn-vrou, our cuckoo, for the first time. His insistent monotonous call drives us distracted as the season wears on, but now we greet him warmly. The morning was not at all first-class as to weather; but we have had a glorious week of hot sunshine, and the flowers are out with a rush. There is nothing quite like the spring display of Cape bulb flowers.

The brilliant golden bells of Lachenalia aurea are fading, and their place is taken by $L$. glaucina, whose soft metallic blue flowers are shown up to great advantage by the glaucous green stems and the leaves deeply spotted with purple.

But the high-light in the bulb plot is the bed of Moraea villosa hybrids. Their stems are so fine, and their blooms so large and ethereal and so diversely coloured, that one immediately gets the effect of giant butterflies about to alight; and the butterfly effect is enhanced when one studies them closely. The peacock markings in the centre of each flower are indescribably beautiful. While those found in the veld are, I think, only found in varying shades of blue, lavender or white, those I have in the garden, which are probably crossed with the deep orange Moraea tigrina, run through every shade of blue and purple, orange, bronze, pale lemon and white, and then the centre markings of every one are different. They have a good flowering season, as each stem carries two or three flowers which open in succession. They are very hardy, and not particular about soil or situation: I have seen them blooming well between the paving stones of the side walks in Tulbagh village streets. 
Then there are plantings of Sparaxis and Streptanthera, which will insist on crossing however far apart one plants them; and here we have been lucky enough to get a wonderful break. Some time back a neighbour was given a bulb said to be a black Sparaxis. Through many years of growing we have heard stories of marvellous bulbs, from blue chinks to yellow Amaryllis, and so we have grown sceptical. We planted them without enthusiasm and awaited results. The description proved to be true! The flowers really were black, or as near as may be, and of a beautiful velvety texture quite foreign to Sparaxis tricolor. Some have gold dots or a gold lacing in the centre, reminding one of Auricula. Some are just plain black. Of course, anyone who sees them wants to buy them, but we are carefully working up the stock. Not all the seedlings come true, but the numbers are steadily increasing.

The gay little Hesperantha Bubrii opens its pink buds at 4 o'clock and becomes a gleaming white star all through the night, while $H$. Metelerkampiae and $H$. Stanfordiae have large butter-yellow blooms on short stems ; and I must allow that the former should have first place, for its chocolate blotches on the three outside segments are a great addition to its beauty. But they are all lovely.

There is a long bed of kalkoentjies (Gladiolus alatus) in full bloom. Their scent of summer apples is quite unique, and so is their colour of terra-cotta red with the lip banded with bright green. I seem to have acquired a very large-flowered strain, and I see some of them are playing tricks with their colouring, showing green where they should be red and vice versa. I think they may have crossed with Gladiolus $W$ atermeyeri; there is the same showing of pencil stripes in the flowers and the long narrow lip of that species.

The planting of Gladiolus tristis is at its best in the evening, when the pale flowers show to advantage and the scent is almost overpowering with its soft sweetness. The species seems to have been grown for more than a century in many corners of the world and is quite the best known of our Gladiolus species. It is also the easiest to hybridize; it makes crosses spontaneously with $G$. alatus and $G$. grandis, but I have 
never seen any of the progeny as attractive as the species. As to the so-called scented hybrids raised in Europe and America, I think the less said about them the better. Unfortunately, $G$. tristis has an unscented form which turns up occasionally and is definitely not worth cultivating; but the scented $\dot{G}$. tristis I consider a first-class cut flower although the florists here at the Cape hardly know it. I think this is due to the strange regulations passed by our Provincial Administration, which aim at protecting the wild flowers by preventing the picking of them in the veld and succeed in penalizing the growers who would prevent their extinction.

But to return to the Gladiolus species and their scent. The rare G. viperatus or green kalkoentjie has the best scent of all. Visitors asked to smell it always say "What does it remind you of ?"- - q question I find difficult to answer. It reminds me of miles and miles of a long, straight road and the rain beating down, and the old car pounding on and on through pools of water on the road, and water pouring through the hood and one bloom at the back of the car cheering us on with its wonderful fragrance, and then at Hopefield a grand welcome and dry clothes and a much-needed supper. Sometimes the collector's memories of plants, people and places are strangely interwoven.

The bulb plot is full of thrills these days. There are beds the length of the orchard, and the plum trees are now in bloom, their white blossoms making a delicate background for the brilliant colours of the bulb flowers at their feet, blue babianas and geissorhizas, freesias, homerias and lapeyrousias in every colour.

We planted all these treasures in February, when the sun beat down day after day and the sand was so hot that it burnt our feet and there was no colour in the fading leaves of the plum trees. Day after day and week after week we toiled. They remained dormant in the ground until the first rains came in April, and as the winter advanced the green shoots appeared. They grew well in the many weeks of deluging winter rain with brilliant sunny days between. There was no frost to quell them and as soon as the first spring days gladdened our hearts the lachenalias began to show colour, and now for 
weeks and weeks there will be a succession of bloom only quenched when the sun burns too fiercely. Then they go to sleep until things cool down once more, and in their sleep they travel to all sorts of queer places and wake up to display their marvellous colours to people who admire their beauty in many strange tongues. 
THE GARDEN is now waking up to a good show on sunny days. Most conspicuous are the bushes of Protea cynaroides (King Protea). The beautiful rose-pink cone-shaped buds washed over with silver sheen take weeks to develop into the perfect flower-head, which is sometimes one foot across, the outer bracts a deep rose and the centre flowers pale lemon. The bushes grow to about eight feet and are spreading. They bear a succession of bloom for several months. Protea barbigera runs these very close. Every bract in its pointed bud is edged with dark fur, and when the blooms expand they show a cone in the centre heavily tipped with black fur. There is a variety with very deep pink blooms and another with cream ones. Nearly related is Leucospermum reflexum, a very attractive bush with small grey leaves and heads of flowers of soft flame-red. As these open they turn back towards the stem, and the styles become very prominent. I have counted 150 blooms open at one time on a bush, and the effect is extremely beautiful.

Then all the daisy flowers open on sunny days, and what a show they make! My enthusiasm is for dimorphothecas, especially the perennial ones. This year is a red-letter date for me-the first blooming of my special hybrids. The original break was, I think, a natural hybrid; and its appearance gives me a clue as to its probable parents. This one I call V.E. It has large biscuit-coloured flowers with a violet ring round the disc, which is usually brown. I was able to propagate this by cuttings, and when I had raised a good stock I crossed it again (and what a job is the hand-pollinating of a composite!). I am now getting results, and they are far beyond my expectations. So far no two are alike. The flowers have again increased in size, and now run through every shade from pale cream to deep gold. In some the ray-flowers are tipped with copper, and some have a copper gleam all over the flower. Some have dark centres and some pale; but not one has the violet ring of the original V.E. daisy. However, I am crossing again this season and hope to get it back. There is one that I think specially good : the flowers are very large, palish gold with deep 
gold centres in the middle of which is a dark brown spot. To speak more botanically, the centre flowers of the disc are a dark brown, while the outer ones are gold, and the ray-flowers several shades paler. There are now seedlings from last season's handpollinating ready to plant out, and I hope to see them bloom this summer. These I call V.J.

All the perennial dimorphothecas like full sun, not too rich soil, but sharp drainage. Where winters are severe they may be kept as cuttings in frames and planted out in spring. Here I cut them down after their spring flowering, and they bloom again in summer if watered. Where they get summer rainfall, they go on blooming nearly all summer. While all the world grows the little annual Dimorphotheca these very-much-better perennial ones are little known. Three really good species of perennial Dimorphotheca are D. chrysanthemifolia, D. jucunda and D. jucunda var.

The first I found in seed in Namaqualand and I raised it without ever having seen the flowers. It thrives here on a slope in the full sun. The great golden-yellow flowers may appear at any time, but in the spring it goes all out, and every plant is covered with bloom. I think it has the largest flowers of any of the Dimorphotheca species. I considered it a very lucky find.

$D$. jucunda has flowers of deep pink with yellow centres, and the leaves are deliciously fragrant. It does not grow into a bush, but is somewhat spreading. D. jucunda var. goes a step further and is definitely creeping. The flowers are the same deep pink, but they have blue centres - a charming colour combination. 
ARCTOTIS SPECIES are now at their best. In Europe the one that is best known is the annual Arctotis grandis; I remember seeing it blooming in a pot in a glass house at Kew. Here at the Cape we do not bother with it much ; it is an upcountry species which needs watering in summer, and though attractive in a delicate fashion there are many better things.

The spring-flowering species of Arctotis are full of colour, mostly running to shades of copper, bronze, orange or crimson. Here I grow the two types. The one that I label Arctotis speciosa hybrid is said to be annual. but here it never thinks of dying after flowering, remaining nearly dormant until the first rains come in April, and then blooming all winter. But they should be sown every year, as after two years the old plants become untidy and scraggy. I think these are some of our very best things, and because they are so adaptable they have travelled through the world. In most parts of England they will come safely through the winter and bloom again in early spring, but where winters are severe they can be treated as half-hardy annuals, started under glass early in spring, and will then bloom through the summer. A bed of these in full bloom in our spring sunshine is a wonderful sight-the colours are so intense and so varied. Here we sow in the open early in April ; they grow in our mild wet winter and are ready to bloom in spring. The other type I call big spreading Arctotis: it is definitely perennial and will go on for years covering more and more ground and making a grand show in spring. A few of these root at the nodes; but mostly I have to layer them, though sometimes it is enough to peg them down into a heap of sand. There are some distinct species among them, but most of mine I dare not send to the botanists to be identified; they would be scornfully termed "garden hybrids".

Quite the best one seems to be a separate species. I call it A. stoechadifolia variety, simply because I had the crimson form of it first ; but it appears to be distinct from this species. It has large very deep red flowers with shining black centres. 
They look very good coming over the edge of a stone wall, the grey foliage just showing through the mass of dark red blooms. Arctotis aspera is a good thing too, having attractive foliage cut, crisped and curled, in very dark green against which the pale yellow flowers are very pleasing. There are some good hybrids from this species, all of which have a very long blooming season and are excellent for cutting. Of course they shut up at night, and so are not suitable for dinner-table decoration. They are all in bloom now, some having flowers of crimson with a white ring round the centre, some creamy-white with a black ring, some orange touched with pale cream at the tips at the rays, others a deep bright copper, and others again a light yellow showing red on the reverse of the ray flowers. They grow and bloom in great profusion, and are certainly worth acquiring for a fairly large garden and indispensable for slopes and terraces in the wild garden. In our hot dry summers, when the flowers are over, the cool grey foliage is in itself refreshing to the eye, and a perpetual reminder of the everrecurring glories of spring.

On sunny days the Mesembrianthemum family make a brilliant colour display from about 11 a.m. to 4 p.m. The name Mesembrianthemum is now restricted to comparatively few species in this vast group, and the showy ones that everyone knows best are now mostly included in the genus Lampranthus. The first of these to bloom here is Lampranthus aureus, its golden gleam flashing out on the first warm sunny day, and how welcome it is! There are bush species of Mesembrianthemum in every conceivable colour except blue, and the colours are always clear, brilliant and intense. They should be planted in bold masses-that is, for people who can stand concentrated colour. I have had people complain that they could not stand the wave of colour in my kloof garden when all the Mesembrianthemum plants were in bloom; others say that it makes them so extremely tired that they have to get away from it. But now I sow patches of the lovely blue Heliophila between the colour splashes, and that immediately gives relief.

The creeping varieties of Mesembrianthemum have often more delicate colours. For instance, there are the lovely shell- 
pink Cephalophyllum anemoniflorum and its gleaming white variety, both lovely things; $C$. Pillansii, which has soft yellow flowers with strawberry-coloured centres, and $C$. procumbens, whose flowers are all yellow. These last two are always in bloom very early on the edge of my terraces. There are many other very beautiful species found in Namaqualand and up the west coast which will not thrive here on account of our very wet winters. I saw Cephalopbyllum Alstonii making a grand show in California, but it is not happy here.

When I was collecting in Namaqualand and came on Carprobrotus guadrifidus, I could hardly believe what I saw. The plants had a way of flinging themselves over scrubby bushes and then clothing them with the most brilliant pink flowers as big as the top of a tea-cup. There is a form with glistening white flowers which is even more lovely. They have done quite well here in a very dry spot.

The Mesembriantbemum is easily propagated by cuttings, except the beautiful Drosanthemum speciosum, whose stems are thin and wiry, but which comes easily from seed. I raise it in tins in the shade in summer or in cement pots standing in two inches of water in the full sun. Then the plants are ready for putting out in April when the rains begin. It makes a grand plant with its flowers of the loveliest flame-red for bedding out or for a roadside display or for a splash of colour on a slope, and it blooms a little later than the others. Most Mesembrianthemum can stand a little frost if the weather is dry, but cold and wet together turn them into a soggy black mass.

The little annual Dorotheanus bellidiformis or Bokbaai vygie is one of the loveliest treasures of the garden. The nearest thing to it is Portulaca, but the former has a range of much softer colours. Here we sow in April, and it blooms in early spring. It likes a sandy soil in full sun, and if left alone will sow itself year after year. It is at its best on the sand-dunes of the west coast where, on a sunny day, the sand appears to be sparkling with jewels of every colour with the sea as a background completing the beauty of the scene. The seed is so fine that it is best when sowing to mix it with mealie meal (sand is too coarse). It may be sown where it is to flower or 
sown in tins and planted out. It has a way of finding just the right spots in which to grow, and will come up between the stones of a path in a rock-garden or in the crevices of a wall where it blooms early and disappears when the days are really hot, but next year it will be there or thereabouts again.

Conspicuous in the garden now are three Podalyria bushes with white flowers, sports from seed produced at the National Botanic Gardens, Kirstenbosch. The ordinary pink-flowered form is very beautiful with its pink sweet-pea flowers on a silver-leaved bush, but the white ones are particularly lovely, having dark green leaves as a background for the dainty white blossoms. The scent of both is entrancing.

Yesterday the big brown Afrikanders (Gladiolus grandis) were at their best on the bulb plot, their two-foot wire-thin stems swaying in the breeze. In their natural state among tall grasses and bush the flowers are almost invisible, their brown speckled blooms with the long crinkled segments fading into nothingness against their background; but at sunset they may be traced by their scent. The brown colour then changes to dove-grey and back to brown with sunrise. What the connection is between the changing of the colour and the giving off of the scent I have never discovered. They should be grown in semi-shade amongst bushes or tall-growing plants; in full sun their delicate blooms are apt to be scorched. 
THE EARLIEST spring bulbs will soon be over. Sparaxis, Streptanthera, Freesia and Lachenalia are now making their seeds, and I have to keep a sharp eye on the early Gladiolus species. A day of roystering south-easter will leave me with never a seed.

Ixias are brilliant. There is a plot resplendent with orange ones that show red on the outside of the segments, and here and there Ixia viridiflora is opening its startling green flowers to show the shining black eye swaying on thin two-foot stems. I never dare to plant more than a few together, as rodent moles will come from all around to eat the bulbs. I once had over 1,000 of these bulbs, but they were stricken with the dreaded Sclerotium Rolfsii and completely wiped out. Now, on new ground, I am slowly working up a stock again, but the probability is that the moles will defeat me.

I have just finished potting up my Protea and Leucospermum seedlings. This must be done as soon as they have four leaves. They are difficult to handle, for the long tap root is fine as a hair, and if damaged the plant dies immediately. They are planted in $4 \mathrm{lb}$. jam tins, and the best way to put them into their permanent quarters is to cut out the bottom of the tin and place in the soil with as little disturbance as possible. Like young turkeys, they will die if they can find the slightest excuse for doing so. They should be planted out on welldrained slopes in full sun, and Leucospermum reflexum definitely does better facing the morning sun. During their first summer, they must not be allowed to dry out, but watering must not be frequent. After their first year they usually go ahead and are no more trouble; and when the blooms appear in their third year one is more than repaid for all the care bestowed. In my garden now I have great silver-grey bushes of Leucospermum reflexum crowned with one hundred to two hundred blooms of fiery red. Leucospermum nutans, the flame-orange pincushion flower, rivals it for sheer beauty of colour and form, its stiff branches making a compact bush covered with yellowgreen leaves. Protea barbigera holds out great shining pink 
cups tipped with black fur, and rising majestic above all there is Protea cynaroides, the king protea, whose giant blooms have been on display for a month or more, and which has several months of blooming yet.

These are surely some of South Africa's best gifts to the world. Where frosts are severe they will not thrive, but I have seen them doing well in California, and before the war a collection was gradually being built up in the south of France.

The klapperbossie or Aitonia (Nymania capensis) is now on show, the brilliant pink lanterns shining out on the short stiff branches covered with tiny leaves. This is a grand droughtresister. When travelling through the Karoo I have admired it from afar, the intense pink of the lanterns being accentuated by the drabness of its surroundings where one longs for a spot of colour. However, it does not seem to mind our wet winters ; it does well here, and it even stands up to the dripping rains of the Cape Peninsula and blooms in Cape Town gardens. The trouble is to persuade the seeds to germinate. They should be soaked for 12 hours or more in very hot water; but even so they will at best take many weeks and may not appear until the following spring. I have tried sowing in spring and autumn, and results are much the same.

Monsonia speciosa, a near relative of the Pelargonium, is now coming into flower and is a real treasure. I grow it on the edge of my terraces, where it is very effective. The leaves, having very fine segments and compact growth, show well there, and when the large blooms appear with the first warm days they are always much admired. Here the flowers are a deep pink, but on poor or sandy soils they are white-veined pink. Collecting the seeds is a great game : each is equipped with a coiled spring, and as soon as it is ripe it is gone. One gets to know the approximate distance to which the springs project them, and fortunately the tip of each large seed is a bright yellow, so that is is possible to find them amongst leaves and weeds. Unfortunately, this plant will not stand even as much frost as they get in Johannesburg, and nothing can be done with cuttings, so it remains a treasure for the frostfree areas. It is a true perennial, though when summers are 
very hot and dry it almost disappears, to sprout again with the first rains. The seeds must be sown in early autumn, when the weather is cool. The seedlings should be planted out just as soon as they are big enough to handle : they make a long tap root and will not stand transplanting later. People who try to stock their gardens free of charge from veld and roadside find in them a strong inducement to bring out their trowels; they dig and dig into the hard ground, the delicate lacey leaves are all champed up in the process, and eventually the long tap root emerges mostly cut and broken. But the plants are taken home and planted, and just so much more beauty dies at the hand of man. 
A WEEK of stormy weather with two hot days. This is a bad spring : there is a wealth of blossom, but we can never enjoy it, and the flowers are quickly over. In an old pear orchard lower down the valley the tiny pale green leaves are breaking through the white foam of blossom, and in my garden are some thousands of white-flowered watsonias repeating the harmony in white and green. Standing out boldly against these a kaffirboom (Erythrina) flashes forth its scarlet blossoms, and it too has a sprinkling of young leaves among them.

On the lower ground, which is never dry, the flowers are coming out and there are great golden spikes of Wachendorfia thyrsiflora showing up among its big clumps of yellow-green pleated leaves. This is an excellent plant for the waterside garden: it looks after itself and flourishes exceedingly, but does not become a pest.

The first crinums are out. These are the old Crinum longifolium (C. capense) which seems to be grown almost throughout the world. Its big heads of pendulous lily-like blooms in white or pale pink, striped with deep pink, are very handsome, and it makes a fine plant for a big pot or tub in a conservatory. The big seeds must be sown as they are ready to leave the parent plant and it will be many years before they come to flowering size; but they do not require much attention. This Crinum likes a good stiff soil rich in humus and should never dry out.

The gem of the genus Crinum is C. aquaticum (C. campanulatum). This one chooses to grow in 1 to 2 feet of still water, and if the water dries up in winter it will do no harm. The hanging bells are a rich deep pink, and the leaves not much thicker than a rush, and as long as the water remains it will go on blooming most of the summer.

Another good water plant is Dipidaxtriquetra. This lives in vleis which dry up in summer, and blooms very early. It belongs here at the Cape. I have heard it described as " peach blossoms on hay" which gives quite a good idea of it. The stems and leaves are thin and reed-like and the pink and white 
blooms are packed tightly together on the 3-foot stems. I have seen half an acre in bloom in a few inches of water-a truly lovely sight. It would do well here in my garden, but every year the land crabs and the mice come and eat off the young shoots as soon as they appear. However, we shall go on trying.

Kniphofia waria grows happily in the stiff black soil; it flowers very early in spring and again in autumn. Before the land in this valley was ploughed and planted with fruit trees, there were acres and acres of these glowing torch lilies lighted every spring in the low-lying ground which had been under water most of the winter. Now one seldom sees them wild here.

Kniphofia Tuckii also blooms early. Its flowers are not the true red-hot-pokers, for their colour is a subdued old-rose fading to cream, but they are very attractive.

We have Knipbofia tritoma in bloom nearly the year round, but the other species will be described in their turn.

On hot days, gazanias make a blaze on terraces and slopes. I think they should only be grown where the sun can shine wholeheartedly. I saw a splendid collection of well-grown plants in London, but how sad and dreary they seemed to me! Here their brilliant shades of orange, copper and bronze gleam and blaze in the midday splendour, but a cloud over the sun for half an hour sends them all to sleep.

A very fine Gazania hybrid which turned up in a Johannesburg garden was sent to me by a flower-lover there who has the outlook of the true gardener. She wanted me to have it because she knew that I should appreciate it. The flowers are large. On opening they are a brilliant chestnut colour with wonderful patterns in the centre. As the days go on, the colour changes to deep crimson and pink, ending up nearly white. Since there are nearly always flowers in different stages of development on the plant, the effect is very charming.

Lately I received from a grower in U.S.A. a packet of seed of his best new Gazania hybrids-they have indeed proved to be wonderful-such size, and the colours! We are not used 
to seeing Gazania in deep crimson with the peacock centremarking on a ring of gold, or delicate cream blossoms tipped with gold or bronze, or smaller dainty flowers of apricot or pink ; but here we have them all. It seems a pity that horticulture in this country should not be taken seriously-we have such a wealth of material to work on. Perhaps that is the difficulty : we have too much. 


\section{TH OCTOBER.}

WATSONIAS ARE beginning to make a show. The white $W$. Ardernii and $W$. Versfeldii, so much alike, are already over, but in their place comes $W$. marginata, which is one of the best and very distinct. At first sight it might be mistaken for a giant Ixia or a Dierama. The 4-foot stems are very thin, and the pink flowers are small and tightly packed, sometimes for $1 \frac{1}{2}$ feet of stem space. In the wild they stand out among the veld bushes, catching the light and swaying in the wind on the hillsides. It definitely likes a well-drained site, preferably on stiff soil.

The little $W$ atsonia roseo-alba is showy now. The stems are only about a foot high and the blooms a lovely soft pink, sometimes marked with white. It grows naturally on sandy flats near the sea but is very decorative in a rock garden. A size taller is $W$. meriana var., also a good pink. All these are excellent for massed planting, especially with a background of Aristea capitata, which sends up its four-foot spikes of deep blue blossom just at the same time. In nature it often grows with $W$. rosea and the effect is splendid on the open hill-side, but in a garden $W$. rosea is to me a devastating shade of pink. But then I believe in discrimination even at the risk of being exclusive.

Watsonia aletroides is a little earlier. The stems are 1 to $1 \frac{1}{2}$ feet. The flowers are usually a deep red, though there is a lovely shell-pink form which I have never seen cultivated. The individual flowers are tubular and pendent, often causing visitors to my garden to declare that it cannot possibly be a Watsonia.

All these watsonias are deciduous, and so where winters are severe they may be taken up and stored, though their natural growing time is in the mild wet winter here at the Cape. The evergreen watsonias come a little later.

It is now a busy time with seed-gathering. The precious Dimorphotheca hybrids have set a splendid crop, all the early Gladiolus species have done well too, but this is a country of wind; gathering Gazania, Felicia and Senecio seeds with a stiff 
breeze blowing is no easy matter. My assistant is an old coloured woman who has worked for me for nearly twenty years. She cannot read, so it is useless to label the bags in which she collects the seeds, but a series of strange marks seems to convey something to her, and she never makes a mistake. She cannot count beyond ten. Some of the precious seeds are sold per thousand, so I had to devise a system of counting with ten small cigarette boxes and ten big ones, and it works out all right. Once she embarks on a job of the sort, nothing short of the dinner bell distracts her attention. She never looks up, but just goes on until the job is finished. I asked her one day if she liked doing the job on which she was engaged; she looked up in wonderment and stated simply, "What Madam tells me to do, I do ".

We cannot get far in conversation: her English is limited and my Afrikaans does not amount to much. I once enquired how old she was, and she replied, "Thirty-seven". I knew that her son was about forty so had to conclude that confusion was caused by her lack of education in elementary mathematics. 


\section{TH NOVEMBER.}

THIS SHOULD be high summer, but we are still getting cool days and rain at intervals. We have now had over sixty inches this year, which is considerably above the average.

On the bulb plot Ornithogalum aureum (miniatum Jacq.) (orange chinkerinchee) is very fine. I think I have a very good strain of it, the stems are over 1 foot and the large golden blooms, six or seven out at a time, are nicely spaced out. The flowers last a long time in water and go on opening out, but not to the same extent as the famous white ones so welcome in England at Christmas time.

Ixia Bloem Erf (I. viridiflora var.) is now coming out. In bud it is a lovely blue, and a good pink on opening. Over 2 feet high, it makes a dainty cut flower. With it comes $I$. monadelpha, of which the individual blossoms are a most attractive blue with dusky brown centres and very large, but the stems are short, about six inches, very showy for a pocket in the rockgarden or as a pot plant. It does best in sandy soil. So we have Ixias for four months, from Ixia scariosa in August to Ixia monadelpha in November, and I am always sorry to see the last of them.

My special bush of Leucospermum nutans continues in a state of perfection. Every bloom is correctly spaced, and shows never a sign of fading. There is not even a shabby leaf on the whole bush. It might be the conventional pyramid tree beloved of cross-stitch artists, though the pyramid is rounded and the colour of the flowers could never be matched by any embroidery silks.

I have seen the first of the fireflies; they evidently come by the calendar and not by the thermometer, for the evenings are still cold. 


\section{TH NOVEMBER.}

MY COTYLEDON terrace is now thoroughly satisfyingin fact, extremely pleasing - to the eye. In this country, cotyledons are little thought of: people have a way of making horrible dog's grave rockeries with a dried-up Cotyledon on the top-enough to put anyone against them. It was not until I saw, years ago, an exhibit of cotyledons at the Chelsea Show, put up by Mr. Theobald, that I realized what could be done with them. Every plant was perfect-not a damaged leaf; all looked the picture of health. Many of them were covered with white "bloom" and what a job he had to keep the crowd from stroking them (" Just feel how soft they are, dear!"), leaving the marks of their fingers as green patches on the beautiful white leaves. Nine are not so good as that; they grow outside and stand up to all sorts of weathers but they are very attractive.

Our over-worked botanists give them scant attention. I have half a dozen or more which, to the gardener's eye, are quite distinct, but they are all called Cotyledon orbiculata. The foliage of all is usually grey, whitish or pale green. I planted them at intervals in clumps the length of the terrace where they show to advantage against the red soil. Between them I planted Drosanthemum speciosum, whose attractive yellow-green foliage is good all the year and just now its bushes are covered with flame-coloured flowers. Then here and there on the edge of the terrace are plants of a particularly good Pelargonium which has no name. The botanists insist that it is hybrid and I must own that it very much resembles one I knew in England as Pelargonium Moorei. It has the divided leaf of the scented geraniums so beloved by the cottage gardeners of England, but the flower heads are showy with their blood-red flowers tightly packed in good-sized heads. The habit of the plant is semi-prostrate, and it looks well growing over the edge of a wall. I have never known it to make a seed. I found it originally on some flat ground near the mountains, where there had once been a cottage and a garden on a farm in the Tulbagh district; but I saw it again years later at a 
Tulbagh wild flower show, and the collector told me that she had found it far up on the mountains.

To return to my terrace. The background is a wall of old red-brown sandstone; and right up against it for the whole length I sowed Heliophila, sometimes called blue flax (which it is not). It came up very thickly, and even after drastic thinning of seedlings it formed a blue mist as a background to the soft greens, greys and white of the foliage of the cotyledons. Just one of my garden schemes that came off: I must own that they seldom do.

Most visitors to the garden show great pleasure when I proudly lead them to this terrace; but occasionally there turns up the one who, casting a casual eye on the cotyledons, will announce: "Yes, you know those plants are very good for curing corns." (I could write a volume on visitors to my garden, but considering that $I$ am a needy nursery gardener and mostly the visitors are customers there are things that are better left unwritten.)

But the cotyledons - the one I like best has the usual thick grey round leaf, bigger than most, and having a distinct point with the margin of the leaf primrose-yellow instead of the usual red. The rosettes of leaves grow close to the ground, and are thickly covered with white wax powder. The blossom is not so good as some, as it has rather a short stem. Another very good one has leaves more long than wide, with a short point and red edge; the flower stems are 3 feet, sometimes more, and at the top a head of pendent blooms, sometimes pale yellow, sometimes deep apricot and all shades between. I once came over the Hex River Pass about mid-summer on a sweltering day when these cotyledons were all in bloom, their cool grey leaves and delicately coloured flowers standing out on their long stems among the burning rocks. No amount of heat causes them distress : they seem able to store up enough moisture in the thick leaves to carry them through, and the wax powder covering prevents undue evaporation. Wet and cold together they cannot tolerate: they stand up to our mild wet winters well, but must be on well-drained ground. A sharp frost reduces them to a black pulp, but a slight frost in dry weather does not harm them. 
There are several others of the $C$. orbiculata type, then there are some with names of their own. C. Flanaganii I planted for its flowers, good handsome heads of pendent terra-cotta blooms showing up well against the grey leaves which are rolled up into pointed tubes. I chose C. Pillansii too for my terrace to make a contrast, because it has yellow-green hairy leaves, also tubular, and its blooms are very distinct, being deep yellow. Then there is C. grandiflora, whose blossoms are certainly the largest of all and a good shade of red. Small green leaves appear in winter and spring, but as soon as the weather is hot and dry they drop off, the plant being kept alive by the food stored in its thick succulent stems, which even without leaves or flowers are quite decorative.

There are many tiny cotyledons, but these really should be classed with the succulents proper, which are not included in this book; they have defeated me with their number and variety.

The extreme edge of the terrace has a dainty decoration of Helichrysum retortum, a very pretty six-inch plant with silver leaves and flowers like large white stiff daisies with yellow centres, a treasure among " everlastings". 


\section{TH NOVEMBER.}

THE GARDEN begins to look more like summer. The first blue agapanthus plants are in bloom; and how welcome they are!

Crinum longifolium (C. capense) is good this season, as we have had rains at intervals and an exceptionally high winter rainfall. This Crinum is extremely handsome with its 3-foot stout stems and umbels of large lily-like pendent blooms, striped and flushed with pink. A very good thing for a herbaceous border or planting at the edge of a shrubbery, it continues to bloom most of the summer as long as it gets water; it is one of the few plants that show to better advantage as single specimens. I have not seen the hybrids between this plant and Amaryllis belladonna (Brunsvigia rosea); but I hear they are good. Crinum variabile does not do well here (probably it dislikes our wet winters), but the rare $C$. Kirkii is very handsome.

Pelargoniums are making a grand show, especially $P$. Burtoniae. It has yellow-green leaves, and its masses of bloom are in a queer shade of red that I cannot describe; the petals of the flowers are very narrow and quite distinctly 3 down and 2 up, giving the heads of bloom a very gay effect, quite different from the smug pomposity of our well-known "scarlet geraniums". Unfortunately this species seldom sets a seed.

In my kloof garden is an enormous bush of Pelargonium inquinans, about 5 feet high and as much in circumference, just covered with heads of soft pink bloom. One may cut 3-foot branches of it and make wonderful decorations in large bowls or jugs. This is probably not the true Pelargonium inquinans, which I think has bright scarlet flowers.

Pelargonium triste is still in bloom. It does not make a startling display, but its tufts of finely-cut leaves are attractive, and the heads of greenish or maroon blossom have a mysterious quality, giving the impression of being very, very old. The plant makes an underground tuber and disappears completely when summers become too hot. Pelargonium ecbinatum has much the same habit, but it leaves a thick woody stem protected by prickles in which 
it stores up its life-force until the rains begin. The leaves drop off after it has flowered, and the hasty gardener (is there such a person ?) is apt to uproot it, thinking it dead.

Another tuberous Pelargonium is P. pinnatum, the loveliest little thing, sending up tiny round heads of pink blossoms among the elegant pinnate leaves. Blooming on the kopjies among the rocks beside the little blue aristeas and lobelias, it is one of the treasures of nature's rock garden. Once I had $P$. incrassatum, one of the showiest of the tuberous pelargoniums, a size bigger than $P$. pinnatum and the blossoms a most brilliant deep pink, but, alas, our wet winters are more than it can stand; it is at home in the dry climate of Namaqualand.

Pelargonium reniforme is another gem for the rock-garden. It remains green and growing all the year, but must never be too wet in the winter. It has grey leaves and brilliant purple blooms. Pelargonium fulgidum also is still in bloom. Its brilliant scarlet blooms are very showy, contrasted with its dark stem and leaves; the stems are succulent, and it enjoys a definite resting time in the heat of summer. It belongs among the rocks of the small kopjies near the sea on the west coast, where the light is very clear and every colour intense.

Perhaps I should mention Geranium incanum, I believe the only South African Geranium-not in the least like the garden "geranium", but very much like the bloody crane's-bill of Europe, or even the common herb Robert of the English hedgerows. It is a nice, compact little plant, having muchdivided leaves and purple-blue flowers. It prefers a fairly damp spot, and will sow itself and come up in odd corners, where it is always very welcome, as it blooms the whole summer.

Dimorphotheca spectahilis is still good. It blooms much longer into the summer than the spring-flowering kinds, and its deep pink rays surrounding the shining black disc are very showy. If kept watered, it is good for bloom right up to midsummer or even longer. 
WE HAVE had a week of perfect weather and plenty of hard work. The birds are awake and giving song by 5 a.m., the piet-myn-vroun's insistent voice rings down the valley, but otherwise at that hour there is complete peace-a peace rounded off by the ctooning of the doves and the robin's plaintive song. When it is 6 a.m., the farm bells ring out, and we must be up and doing. The rattle of watering-cans begins, and a boy stands by the stream of irrigating water and gently directs it to tomatoes and mealies. All day long the work goes on, mostly seed-collecting for me and taking cuttings of mesembrianthemums and pelargoniums now that they have finished flowering, while the boys wrestle with the overwhelming weeds, worse than ever this year because the rains continued later than usual.

When one is thoroughly exhausted at 6.30 or 7 p.m., it is good to sit on the stoep and watch the milky purple shadows creep up the foothills of the great mountains; and once again there is silence. All day the little coloured children whose mothers are working in the vineyards fight and yell; children of five and six are paid to look after infants whose screams rend the air until someone gets desperate and a mother is sent to quell the disturbance. But by sunset they are all at home far down the valley, lighting fires and cooking the evening meal ; and with us "peace comes dropping slow".

A rosy glow, the reflection of the sunset, lights up the great peaks. While the purple shadows creep slowly up towards them, the glow fades, the shadows have reached the summits, the distant ranges can hardly be discerned, a few stars glow dimly, and night is here.

And how nights vary! Since I always sleep outside, I am an authority on nights. I acknowledge that most nights are just a time to go to sleep, and we who work hard outside all day find no fault with that; but there are many nights that are quite different. Sometımes it is all jollification : that is when the frogs take over. They have grand assemblies where everyone shouts at once, and then two will hold forth in a dialogue 
which reaches heights of rancour beyond human levels; and as all the relatives join in the din becomes louder and louder. But one frog has a shout peculiar to himself. In the middle of the uproar he announces " hip, hip hooray" in long-drawn-out and throaty tones which just give that touch of the ridiculous that brings all the heated arguments crashing. I have never known whether the frog who bursts in in this way is of a different species or is one trained to keep the community at peace. Anyway, I am convinced that my frog chorus is superior to that produced anywhere else on the face of the earth.

Quite different from the rowdy nights of the frogs are the very calm nights without the whisper of a breeze, when little sounds and tiny rustlings make themselves felt rather than heard. Often these are the nights when a great round moon sails up from behind the mountains and gradually turns the valley to silver. There are queer unaccountable shadows; the arum flowers along the stream catch the light and become brilliantly white; and one has the impression of movement everywhere. There is nothing of the "ghoulies and ghosties" about these nights; everything is friendly and full of fun and intensely beautiful.

But there are nights when things are not so good, when the winds howl, the wistaria lashes against the roof, rain crashes down in bursts, and mountain torrents rush raving down the valley. Then it is best to turn one's back and go to sleep : when nature's forces are let loose we humans can take no part. In the morning the fury will be over, and we shall be left to pick up the pieces. 


\section{TH DECEMBER.}

MY BOLUSANTHUS tree is in flower. Perhaps it is hardly a tree-rather an elegant bush about 7 feet high. It is rather like those beautifully-grown wistarias raised in big pots in England, trained over supports, and when on show a mass of bloom. I expect this is just another relic of Chelsea in a dusty corner of my mind. But Bolusanthus is more delicate both in flower and foliage than any wistaria, and needs no supports. The leaves are a pale yellow-green, and the flowers are lovely racemes of navy-blue blossoms. Usually the weather is very hot at this time of year, and then the blooms are short-lived; but this year has been cool, with rain at intervals, and the bush has been perfect for a fortnight and shows no signs of fading. Unfortunately it has never made any seed here: it belongs to the much warmer regions of the low veld up to Rhodesia. It likes plenty of water in summer. I have it on a steep slope so that our winter rains do not distress it, and irrigation water runs there in the summer.

Gerbera Burmannii is in bloom. I am beginning to realize that this is just as much worth cultivating as $G$. Jamesonii. It may not prove as amenable. It is very slow, but in this locality with its hot dry summers it is hardier. It only asks to be left alone. It is found on the hardest and driest slopes, and on the poorest of soils. If chopped out and planted, it will struggle through and bloom in time. The beautiful soft pink blooms with their shining black centres are as good as any of the hybrids from Gerbera Jamesonii, and the blooms have the same lasting qualities and artistic display so dear to the hearts of those who compete in the decorative classes at the flower shows. The seeds germinate well; but I think it will be three years before they arrive at flowering size.

I have yet another Gerbera, seed of which was sent me from the Transvaal. The blossoms are said to be pink, but I have not yet seen it bloom.

Last winter I found a plant of Lobostemon in flower in the veld, I took home cuttings, and plants from these are now making a good show. The flowers have the true " borage " colouring, 
brilliant blue with a suggestion of pink. The plants I have are more spreading than erect and about 1 foot high. I have made a note to plant them on the edge of a terrace: blue flowers at this time of year are specially valuable.

The garden has a gay effect with masses of white Agapanthus showing up the lovely blooms of Hesperaloe Engelmannii, seed of which was given me by a kind friend in California. The Catalpa trees are in full bloom and are much admired. Between these the jacarandas and scarlet-flowered gums are getting their blossom display ready for Christmas. But except for the white Agapanthus all these are only very welcome guests in this country. Without them my garden would make a poor show by midsummer. 


\section{CHRISTMAS EVE.}

THE GARDEN is gay; but the scarlet hibiscus, deep blue hydrangeas, jacarandas, sweet-scented romneya, red-flowered bottle-brush and all such things are not South African natives and are well known in gardens throughout the world. But there are watsonias making a fine show, mostly hybrids from $W$. tabularis. They have good spikes of scarlet, flame and salmon; but the flower-beetles do their best to destroy them.

Then in moist shady places the first blooms of Vallota are alight. They show the most satisfying red of any flower that I know: the best shades of the hybrid Amaryllis are muddy compared with it. In vain do I try to persuade these plants to set seed. Last year I hand-pollinated every bloom, and the ovaries swelled hopefully. One day I went to visit them and was entranced to find a beautiful butterfly hovering over the flowers. A friend with me remarked that I might have saved myself the trouble of pollinating, as the butterfly would do it for me. Ten days later I went to look again. Every stem was lying wilted on the ground, and in each a fat caterpillar was established. Eggs had evidently been laid just where the pedicels joined the main stem, and the resulting grub had burrowed its way down. I now have bitter feelings toward that beautiful butterfly.

We are urgently lifting bulbs as fast as we can, for the rodent moles are busier than ever. They have left me with about half a dozen bulbs of the treasured Antbolyza ringens (Babiana ringens), half of my black Sparaxis are gone, and many other treasures. The worst kind of mole makes no heaps or mounds to show where he is working. He has small runs at the level of the bulbs; these lead to deeper and larger runs where he makes his store and also his nest, which is usually lined with the outside coats of Sparaxis bulbs; and his young are fed on green ixias.

Our research workers give us instructions as to how these creatures are to be dealt with. I suppose they are under the impression that their methods are successful ; but I have never met the grower who found them to be so. If we could get 
over this trouble here at the Cape, we could grow bulbs for the world. Soil and climate are perfect, and there is marvellous material awaiting cultivation in quantity; but all our efforts are in vain owing to these devastating rodents.

The seedling bulbs are left in their beds until they have gone dormant for the second time. We sow in March and April when the rains begin, and they take about a month to germinate. Then we take them up about midsummer the second season. There is nothing for it but to sift through the sand with a trowel. Some of the smaller geissorhizas and romuleas match the soil exactly and are smaller than a pea. It is a work of patience to collect them. Lachenalias and orange ixias are much easier: their tiny bulbs are white. But it is not unpleasant to sit on a sack in the hot sun turning over the seed beds and extracting the treasure. Of course the true gardener's mind is full of a picture of these thousands of gladiolus species in bloom in the spring, or of whole beds of gleaming ixias and sparaxis, somehow better than they have ever been before. Seeing a gardener at work, the onlooker thinks what a tedious business it is, and wonders that anyone can stand up to it. But the onlooker does not know half the joy of the gardener : he only sees the flowers that really happen, whereas the mind of the gardener is nourished and delighted with the sight of flowers "that never were on sea or land". 
EVER SINCE Christmas we have been struggling with heat and drought. Every ounce of energy is commandeered by the watering-can. In the early morning it goes gaily enough, the air is still and cool, and the sun at 6 a.m. just catching the top of Simonsberg. I start the irrigation water running on to the tomatoes and mealies, and while directing that I run round to special treasures with the can. There is a good group of yellow gloriosas which must not get dry. They are quite lovely. I begged the boy to get them really tall sticks with plenty of branches for their twining tendrils, and he thought he had done well when he brought 4-foot bushes; but they are already well above these, and I shall not know now how high they could go with adequate supports. Every year I have to fight the moles to keep the gloriosas, and last season I lost all my red-and-yellow ones $(G$. superba).

By $7 \mathrm{a} . \mathrm{m}$. the sun is on the garden. The boys arrive and there is a rattling of cans : peace is over for the day. The boys leave again at $6 \mathrm{p}$.m. and once again I am hard at it with the wateringcan. But at this end of the day it does not go so well, and I only do what is really necessary.

Seedlings have done well this summer. There are fine tins of Baubinia Galpinii and Aitonia capensis. Various erythrinas, kniphofias, gloriosas, Haemanthus natalensis and Ornithogalum Saundersiae show 100 per cent. germination. Now seeds received from the American Amaryllis Society are coming through, various Habrantbus species and other treasures. The alstroemerias they so kindly sent I shall keep until later. When the weather is cool and the rains begin, I sow them in seed beds with my bulb seeds; and they germinate well. I must confess to a great weakness for alstroemerias-not the horrid little red-and-green one (Alstroemeria psittacina?) which haunts our gardens (I wonder who introduced it !), but the lovely tall A. ligtu, A. violacea, A. chilensis and hybrids. These have lovely soft colours, so fresh and dainty, a fine flower for cutting; and they do well here if we can find them a place in semi-shade which is not too wet in winter. But this is a book on South African plants! 
There is now one very bright spot in the garden. Brilliant glowing colour shows up from a plot of watsonias. The spikes are 4 feet high and the top 2 feet of these are closely packed with large regular orange blooms having a beautiful solid texture. They always have a queer kink or twist in the flowerstem, mostly about the point where the flowers begin. So, instead of the usual stiff flower-spikes all upright, the flowers stand out at all sorts of angles. This makes then just perfect for putting up in big bowls or jugs. So far as I know this watsonia has not been named; and of all my watsonias it is the last to bloom except $W$. Galpinnii, which waits for late autumn.

Dierama pulcherrimum is looking fine near the waterfall. The flowering spikes rise 4 to 5 feet and then turn gracefully over. Each dark wine-coloured bloom is pendulous on a hairfine pedicel, trembling and swaying in the slightest breeze with silver bracts catching the light. A friend to whom I displayed them with pride told me how she had seen them by the thousand on the Drakensberg Mountains in Natal, and every shade of pink and putple down to white.

The starry-flowered Jasminum tortuosum is attractive now; and its scent is the real thing. If given something it can climb on, it looks after itself, twisting its delicate branches round any support available.

By the side of the stream, Nerine appendiculata has been in bloom for weeks. It is certainly very handsome with its 3-foot stems and large heads of bloom; but its particular shade of pink does not just appeal to me. However, a big pink nerine which blooms at this time is not to be despised. 


\section{TH FEBRUARY.}

WE HAVE had weeks and weeks of blazing sunshine and hot drying winds-no rain for about three months. The garden looks sad indeed. My tallest Silver Tree (Leucadendron argenteum) has given up the struggle and young leucospermums here and there are dead and brown. Each night and morning sees a mighty battle whose weapons of offence are wateringcans, tins, buckets, and streams of irrigation water. The cuttings in the frame, though shaded and watered, fail one by one; but seedlings flourish. There are tins of Gerbera, Erythrina, Baubinia, Kniphofia, Aitonia, etc., which all look thoroughly happy at my expense, like well-fed cuckoos in robins' nests.

The coloured boys take the opportunity to try out every trick to save themselves from doing any work, or they steal grapes to make must and become so outrageous that one must perforce dismiss them.

The hillsides are bare and dry : there is no feed for the goats. Every day we study the weather-glass and say: "It must rain soon".

The work with the bulbs goes on. Most of the beds of flowering-sized bulbs have been taken up, the big ones sold and the small ones kept for re-planting. Except where the moles have cleared the beds, they are very good indeed this season; and they are badly needed. Never has there been such a demand for bulbs, for even South Africans are beginning to appreciate the native plants.

We sit for hours on end sifting out the tiny bulbs. The ground is so hot that one must sit on a sack; and one learns the advantage of a trowel with a wooden handle. I have two young coloured boys to help me, one very young. He looks about nine, he talks without ceasing, words pour from him for three solid hours without a break. Sometimes his narrative becomes wildly exciting; he demonstrates with arms and legs, and bulbs fly around; then I have to do the heavy, and all is quiet for a while, but it soon starts up again. Apparently his audience of one makes never a sound, and seems to take very 
little interest; and of course it is all wasted on me because I do not understand his language.

I am trying some experiments in vernalization with Leucospermum seeds. In the ordinary way we cannot sow here until April, and that is just when growers want to put out their plants so as to give them as long a growing season as possible. I find that when I sow in April they come through irregularly in May, June and July ; and people who have ordered them are by that time getting more and more impatient. I do not think it is a good thing to keep them through the summer in tins, though it can be done; and if one leaves them in the ground by autumn, when they could be moved, the roots are too long for any tin. So we must find some way of persuading them to germinate earlier. We shall see what soaking and freezing will do; but I feel that Russian wheat is far more amenable to treatment than these individualistic wildings from the rough mountain slopes of tough South Africa.

There are cheering signs that the worst of the summer is over. The early mornings are cool and still, and the mountains provide a background of blue and gold. The robins are back from the bush, and I hear their song very early or after dusk - a small and querulous song, for he is shy and seems to have forgotten all his former intimacy. The long-tailed sugar-birds are having a good time in the flowers of Kniphofia wvaria, the long tail floating out on the breeze suggesting a streamer on the handle of a torch.

A very pretty sight is the Virgilia tree, now covered with its second crop of pale pink sweet-scented blooms. It has a special attraction for the tiny double-collared sugar-birds. I expect that only they have beaks small enough for the blossoms. They hover round the tree, darting in to the special spray that takes their fancy and the sun glints on the brilliant green plumage of the males with its conspicuous ruby-red splash on the breast. So much intense colour and movement in so minute a fragment of life! 
A GREY day at last. At this stage in the summer, the sun is almost an enemy; for months we have known no rain and life becomes a struggle to keep plants alive with the everpresent watering-can.

After a blistering day yesterday I woke to find clouds on Simonsberg at last. It may be that they will disperse and we shall have no rain, but at any rate we shall have had a respite from the fiery brilliance. At this time of the year the sun seems like one of those overwhelming parents who manage family affairs so perfectly. Much beloved undoubtedly, but-oh, what fun the children have when such a one goes out for the day! The birds feel the relief from the sun's all-penetrating gleam; I have not seen so many about for months. The robins are back from their mid-summer moult. After bringing up their family they disappear into the bush thoroughly shabby and worn out, to reappear in a complete new outfit and behave as if they were lords of creation. As always, a pair stake out a claim to my stoep. They appear with extreme regularity at meal times provided that the cats are absent, and their querulous little song is one of the first indications of coming autumn; when they are angry or frightened there is no mistaking their very firm " tut, tut". They are charming gay little fellows, and with the expenditure of some patience and small quantities of butter and cheese one may have them as friends for life.

The small sugar-birds are very much in evidence to-day too. The male has a brilliant blue-green coat with red flash across the breast, the female is clad in sombre browns and greys, just a tiny "little woman in feathers". Both have the long beak for collecting nectar from long-tubed flowers. They have been enjoying the bird bath at intervals all morning. The sugar-birds attract by their appearance only, their voices are harsh squeaks, but one can't have it all ways. It is seldom that beauty appeals to both eye and ear in one form. Is that why ballet takes us straight into the world of faerie?

This morning I sowed another hundred seeds of Gerbera hybrids-rather late in the season, but I have to wait until 
my last year's seedlings have flowered in order to get seed. It is useless to try to buy seed : one gets a packet of fluff with hardly a fertile seed among it, and it will not germinate if more than three months old. These seeds have the reputation of being very difficult to germinate, but given fresh fertile seed nothing is easier. They must, however, be sown the right way. Take a tin (or "flat") of fine potting soil, and put the seeds in one at a time, with the pappus or fluff sticking up and the blunt end of the seed firmly pressed in. Then there is seldom a miss in germination. Anyone who has watched a dandelion seed sowing itself can see just how it is done.

The world seems very still and quiet with what Miss Rider Haggard in Norfolk describes as "the still secrecy of late summer"; there is no breeze, and the wings of the tiny birds as they fly past on their way to my ripe figs seem to make a loud noise. Fortunately on Sundays we are spared the loud bashings of tins by small boys in the vineyards; they are supposed to be keeping the birds off the ripe grapes, but in reality they are eating more than the flocks of mouse-birds or starlings dislodged by them on one side of the vineyard only to settle on the other.

Baubinia Galpini is in flower, a beautiful shrub blooming from mid-summer onwards, when we badly need colour in our parched gardens. It is not quite a creeper or climber, but does best with some support. The flowers are not exactly tomato-red, but slightly pinker. The clusters nearly cover the long branches of dark green leaves for at least three months. I have it backed by silver trees and a solid bank of the grey foliage of Leucospermum reflexum-a most satisfying combination, and quite by chance, as my happiest plantings mostly are. 
SINCE MY last entry we have had alternations of devastating heat and south-easters. The south-easter is just the essence of dryness. Sometimes it blows for two or three days : then our skin feels parched, our nerves on edge and our heads splitting. The trees and plants look as if they were feeling the same way; they are treated to every kind of indignity, and before they have recovered from one onslaught they are bowled over again. Leaves, twigs and branches go flying, acorns rattle down, and dust is carried for miles. Suddenly it ceases, and utter exhaustion prevails. Then we get a day or two of intense heat with never a breath of wind until we long for the southeaster back again.

Yet through it all we realize that we are nearly at the end of our troubles. The first belladonna lilies push through on the cool side of the kloof, and here and there a Haemantbus coccineus glows red among the dried-up bushes. Every year they give me to wonder. The ground is so dry and hard that it would need a pick to break the surface, and yet these delicate blooms find a way to emerge. There has been no rain to tell them that autumn is on the way, and yet they come about the same day by the calendar every year. There is a tiny delicate Gladiolus (G. brevifolius) which also comes through just at this time. About nine inches high, it too grows in the hardest and driest ground: how it manages to push its way through remains a mystery.

All of these plants have no leaves until the rains come in April ; these do their work in winter, storing up food to allow the bloom to get ahead of all the hundreds of winter and spring flowering plants that we shall welcome later. 


\section{TH MARCH.}

ANOTHER WEEK of heat and drought; we are almost at the end of our resources. We had two cool days, and I-always an optimist-rushed forth and sowed seeds in the open. Now we have two more plots to keep watered. But what can a poor nurseryman do? As soon as the rains begin, people want plants; so the plants must be hurried along somehow and by the skilful use of shades, water and compost the seeds must be persuaded to germinate before their natural season; but, as an old hand once said to me: "Anyone can grow plants in season".

Through these hot days I long for my white flowers. For weeks and weeks in December and January I had a hundred or more big clumps of white Agapanthus blooming below the terrace on which stands my cottage. Behind them was a tree of white-flowered Baubinia, and for some weeks with them bloomed my much-loved Catalpa trees. Their white blooms are almost like orchids when looked at closely, and in the distance like glorified horse-chestnuts. We saw them as street trees in America; what welcome shade they give, and how delicious the scent of the blooms! In winter I love them just as much when their bare twigs trace the perfect outline of the tree and the delicate curve of every branch.

Now all these white flowers are gone; yet in a month or two we shall have white flowers in plenty. My garden is a saucer in the hills, for on every side but one steep banks slope up to my neighbour's vineyards. As soon as the winter rains are well under way, these banks will be gleaming with tall white arums. They come up in every neglected corner of my garden (and there are many), so that on moonlight nights one may walk straight into fairyland.

A still night at full moon in this clear air is unbelievably beautiful. I once had a fine row of pink hollyhocks which I admired, but when I saw them by moonlight they were no longer "blowsy maids of hollyhocks" but etherealized. Their pink, all silvered over, seemed not to belong to this world at all. So many people say: "I don't like white flowers". Well, I don't agree; but I know they have not seen what I have seen. 
We all love our masses of intense colour in spring-the daisies each more brilliant than the last, the vygies gleaming in the midday heat, and all the array of bulb flowers; but when all this is past the white flowers seem to me like " the still small voice", the ultimate core of things, something perhaps we never quite grasp or only for a moment in passing.

To-day I have been taken by a friend to see a piece of vleiground that was completely burnt out about nine months ago. The ground was still quite black-no cover at all except the stumps of protea and other coarse bushes and big grasses that had completely filled the place. But, as if to compensate for all its ill-treatment, pushing their way through the hard black soil were hundreds of belladonna lilies in varying shades of pink and white, so poignantly fresh against the charred background. Between them were pushing up groups of Buphane ciliata. Though their individual blooms are small, the whole umbel is attractive with its pink stems and pedicels in the candelabra head. Then there were the brilliant Haemantbus coccineus, almost scarlet in colour, pushing through the hard ground. None of these plants will show any leaves until the rains come next month, and the brilliance of all the varied colours of the flowers gives the impression of a flamboyant emboidery on a black background. I have lived here over twenty years, but I had never seen this Buphane in flower before. Now there are hundreds. The superficial observer can easily explain it: "they only bloom after a fire". Yes, but the blooms are formed in the bulb the season before. Do they remain dormant year after year until there is a fire again, when all the enveloping grasses will be cleared away and a good dressing of wood ash scattered over them?

In the garden I have in bloom two beautiful heads of Brunsvigia banksiana. This is not a Cape species: it blooms with the leaves and expects water in summer, coming as it does from the summer rainfall area. I think the individual blooms are larger than Brunsvigia gigantea (now $B$. orientalis): the pedicels are long and delicate, and the flowers a lovely clear pink, a very much prettier shade than the belladonna lily with its sugaricing hue. This is undoubtedly the best Brunsvigia I have seen. 


\section{RD MARCH.}

A SUPPER picnic to Wemmer's Hoek! A grand event in these days of failing cars and restricted petrol; but here is a friend with a luxurious car filled with carefully hoarded petrol. We started off about 5 p.m. as the sun was growing less fierce after a grilling day of packing bulbs.

We went into the kopjies round the other side of grand old Simonsberg, and I was dropped to go plant-hunting while the rest of the party bathed in the river. It was rough walking on the sun-scorched slopes, and so dry that twigs and small bushes just crumbled when trodden on; but up and up I went to get young plants of Aloe plicatilis where the old plants stand out against the sky line as if posing for a poster- "Come to sunny South Africa". This is a very attractive aloe and one of the very few without thorn or prickles. The leaves are reminiscent of the old linen-fold wood carving. I think it is only found in the south-west Cape : it does not stand up well to frost. Here it is at home among the kopjies with queer rocks of odd shapes lying around. In the spring the whole place is a flower garden; but now it is as dry as last year's pine needles. It looks as if a number of gnomes had had a competition in rockgarden design, each hummock or outcrop having just a slightly different plan of planting - a big bush here, an aloe there, a tuft of grass above or below.

I sat down and watched big blue shadows of the mountains creep across the wide sunlit valley, just as a realization of a deeper or inner meaning to things seen passes slowly across the mind, leaving always a softening of the brilliance of perception but a deepening of shades.

There were lovely soft lights on the river as we went down for supper. The children had made a little fire among the stones at the edge of the water and had a supply of hot coffee ready. How we all enjoyed our eggs and veal loaf and apples and big purple grapes! We watched the first stars come out, and then the Southern Cross was there and we must start for home. The children were thrilled by the sight of a vast fire raging on the distant mountains-an entrancing picture, but terrifying to me. Jennifer summed it up well: "Beautiful, but very cruel". 
A'T LAST relief has come: we have had a good night's rain, and soft showers are still falling at intervals. The people with acres and acres of vineyards and grapes still uncut will not be pleased. The grapes will split and be messy to pack, but they have had the perfect season so far.

Many of my silver trees, proteas and leucospermums are already dead; but others will now be saved, and the seeds I sowed in the open should germinate well, for the soil is still warm. Now there is everything to be done before winter is on us.

We have not had enough rain to wake the mountains into life. All the summer they stand grim and silent withstanding scorching sun and mountain fires, but when the winter rains begin one becomes conscious of a familiar sound that has been long absent-something good in the undercurrent of one's mind. It is the mountain torrents crashing down: their distant roar is an accompaniment of which we are hardly conscious, for during about four months of the year we hear it day and night. It is a background to the croaking and clicking of the frogs and the beating of the rains; and perhaps we notice it most on the glorious still sunny days between the storms, or on the moonlight nights when the arums along the stream sides are touched with silver. When it ceases, we do not notice at first, until the scorching summer becomes more and more silent because the birds have gone into hiding in the bush and the frogs have disappeared into the soft mud around the shady pools. 
IT WOULD be interesting to look up records and see in how many years and in how many places Good Friday is a glorious sunny day and Easter Sunday and Monday cold and wet. How well I remember in my childhood days picking primroses in the woods on Good Friday, the sun shining, birds singing and the stupendous feeling that nothing was too good to happen, for spring had come again! In the background was the knowledge of a new frock and hat to be worn on Easter Sunday, and possibly a picnic to the sea on the Monday. But it was always a case of "Gather ye rosebuds while ye may"; for Easter Sunday always came in cold and wet, and we were sternly bidden to put on our winter coats for church. We would hope against hope for the Monday; but we usually had to buoy up our flagging spirits with "Rain before seven, etc.," and later we would try "Between one and two you'll see what the day is going to do"; but usually we stayed at home.

Here this year, as usual, we had the most perfect Good Friday, and campers poured forth clad in the scantiest of shorts and had their one perfect day; but Saturday came in wet with showers all day, and Sunday morning is clearing but cloudy.

As for me, Easter always means seed-sowing, and Thursday this year was two days before the full moon. I am an ardent believer in the moon's influence on germinating seeds, so I worked away all day sowing Protea and Leucospermum seeds. These I put in every year with high hopes, but the more I ponder the question the less I can account for the results that I obtain. Some years they come well and quickly : more often they do not. Sometimes a few come right away, and the rest germinate in spring or the following autumn. Sometimes old seeds do best; sometimes only the fresh ones show signs of life. However, we go on and take what we get and don't expect too much.

The high-light in the garden now is Liparia sphaerica; and my one plant is truly a magnificent specimen. It is the first 
time I have had it in bloom. I must own that it was neglected in its youth and had to fight its way through thick weeds, with the result that it now stands eight feet high, with its nodding heads of flaming orange a most conspicuous feature among the proteas and silver trees. It has seven fine heads in full colour, and more to come. Each head is over four inches across, the brilliant orange pea-flowers being packed tightly into the nodding heads. It is a great joy to see a wilding like this respond to our efforts at cultivation, and to think that the seeds will eventually travel, giving joy to lovers of rare plants in many corners of the world. I had the seeds from a friend who collected them near Cape Point - a kindly act bearing fruit that the giver did not live to see.

The cooler weather has given us that spring feeling, although it is really the first stirring of autumn; and so a neighbour and I set off for a tramp up the slopes-a thing I have not done for many a long day. At this time we are always spurred on by the thought of finding a white Haemantbus. As it was, we did not even find a red one; these are in bloom now, but we were on slopes too hot and dry for them, and we did not succeed in reaching the intake of our water supply, below which we knew they grew. We struggled through bush above our heads, and were pricked and scratched, and saw never a flower; but it was well worth the effort. We had a grand view of the valley with all the farms and woods below us, a ridge of mountains behind us, on one side the giant range of mountains which my cottage and garden face, and on the other old Simonsberg with the farms running up the lower slopes and black patches where the fire raged for days a few weeks back, and, above all, the unchanging rocks. A grand expanse-and around us miles of slopes covered with bush and big coarse grasses, and the only signs of life two large porcupine burrows with a detached quill lying near one and the long-tailed sugar-birds happy in the protea bushes, which were already in flower. They were the pink and the white forms of Protea neriifolia, very attractive with the brown fur decorating the edges of the half-closed cups. Coming back I found some plants of Lobostemon, from which I collected a number of cuttings. I want to 
see it in quantity on the edge of my terraces; I am also trying it from seed.

Not much from a collector's point of view, but a very pleasant morning's tramp; and we came back with that superior feeling that we can still do more than the young people. 
WE HAVE had a fortnight of perfect weather for the gardener, small rains followed by day after day of brilliant sunshine with no wind stirring. This is a country of high winds. The air is very seldom still ; all summer the south-easter is just round the corner ready to fall upon us, and winter comes in with raging south-westers; but now we have the perfect time between. The garden, exhausted with summer's heat, takes time to recover. A great silence prevails, a still waiting for the struggles to come. Exhausting, some people call it, but the gardener loses not a moment. The ground is dug and raked to a fine tilth, and out he goes, seed packet in hand ; it is a case of now or never with those fluffy seeds of gazanias, arctotis and felicias. It is the time for sowing bulb seeds too. Gladiolus can only be sown when there is no wind, and I have all the beautiful little gladiolus species to sow. How I revel in seed sowing ! I suppose every gardener does; as the long drills are filled in I see them all in flower. Not a seed fails, no grub triumphs, no mole destroys. Beauty is indestructible, and if to the onlooker our gardens are sometimes of little worth who shall evaluate what they give to the minds of those who love them?

The first proteas are out. Lovely bushes of $P$. neriifolia are covered with the goblet-shaped blooms of silvery white tipped with black fur. I have the pink form of this one, too, and it is a lovely soft pink. But the long-tailed sugar-birds (Promerops caffer) treat them very badly; they sit on the edge of the blooms and dig their long beaks deep into the flowers for honey, but they are too big for this game and they damage the blossoms. Their weight spoils the symmetry of the cup by bending it down on one side or forcing it open, yet one could never drive them off. They have more right to the flowers than we have, and they pay for what they take by carrying out the work of pollination.

In the bulb beds Lachenalia rubida is already in bloom. It comes with the first rains ; unfortunately it is too small to be of use commercially, but the colour is delightful.

Gladiolus psittacinus var. Hookeri is out, its brilliant scarlet 
and gold blossoms blending so well with the autumn colourings of the vineyards and orchards. It stands over 4 feet with 2 feet or more of blossom, and is the hardiest and most prolific gladiolus ever known. Nothing attacks it, moles dislike the bulbs, no thrips or rust or caterpillars are known among it, and it blooms when the big garden gladioli are well over. In England it blooms too late and is caught by the early frosts; but in the south of France it is entirely happy, and, blooming in November, is a gold mine to the florists. I do not think that it has been cultivated in California, but when it is there will be a fortune for someone. It has a curious habit of making runners with good-sized bulbs on the end, and one's stock is soon increased tenfold. Here it is quite useless to florists and nurserymen: it is so easy and increases so rapidly that everyone has it. I was lucky enough to have it first: it was sent me by a friend in the Transvaal who rescued the bulbs when ground was ploughed up to make a new golf course.

It has always seemed to me that from this species might be raised a stock of thrips-resisting hybrids, for it would undoubtedly cross with the big commercial hybrids. It may be that it was used originally to produce these, but I am inclined to think that it was the yellowish-red somewhat hooded form from the Northern Transvaal rather than the brilliant $G$. psittacinus var. Hookeri that produced the old brencheyensis and gandavensis hybrids. It is undoubtedly " a good doer". I have heard of an airman in flight coming down from the heights to find out the explanation of half a square mile or so of flaming scarlet veld amid the rolling hills of the Transvaal.

It is rumoured that seeds of this species sown in April bear flowers in May of the next year; but I think this is very doubtful. Anyway, the bulbs produce so many cormlets that who would want to grow it from seed? 
A WEEK of storms, rain, hail and driving winds. Rain falling in torrents for days on end, dripping through the roof and pouring down the slopes in the garden. Yesterday it began to clear; but it was bitterly cold and the garden sodden. Now to-day everything is perfect-glorious sunshine and a slight breeze with big white clouds sailing high-snow on the tops of the blue mountains which seem to have grown higher in the night. Now the seedlings show up in the beds, and the winter flowers come into their own. Barleria makes a brave show in blue on a sloping bank: this is a really good thing. I find it lasts well when cut: the first flowers drop, but others open. My plants have scrambled into a plumbago bush higher up the bank, and present a solid four feet of lavender blue blooms. It ripens no seed here, probably on account of the wet weather; but I find it roots easily from cuttings.

The white and cream ifafa lilies (Cyrtantbus Mackenii) and pink nerines ( $N$. filifolia) are quite charming together, and of the aloes $A$. pluridens and A. rariflora are the first to burst into flame, but I see fat buds pushing up on several different species. They remain to light up the garden all winter.

The long bulb beds are now all green. In Europe bulb plants mostly come up in spring, and bloom as soon as the weather is warm enough; but here they come through the ground with the first rains in autumn, grow all winter, and are ready to welcome the coming of spring with their first gav blossoms. This troublesome habit of growing in winter bothers growers of Cape bulbs the world over, for where winters are cold they will need some protection. Also once they have started to grow they must not be allowed to dry out until they have flowered, so where winters are dry they must be kept watered, preferably on warm days. No amount of rain in winter worries them at all, but it is not so good if they get it late into the spring.

Gladiolus odoratus is already out, some hundreds of them in bloom at once. The scent is marvellous-rather like hyacinths, perhaps, but more elusive. The stems are $1 \frac{1}{2}$ to 2 feet high, with five or six blooms out at a time, the colour something 
between brown and maroon, with all sorts of chequered markings in primrose shades. It reminds me of the fritillarias which we used to pick in a special meadow in Suffolk, and which are so well described by V. Sackville-West :

where the springing grass

Was dulled by the hanging cups of fritillaries,

Sullen and foreign-looking, the snaky flower,

Scarfed in dull purple, like Egyptian girls

Camping among the furze, staining the waste

With foreign colour, sulky-dark and quaint,

Dangerous too. ... .

However, my gladiolus is more cheerful : it does not hang its head, and its allure is not so deadly. But it has a great fascination for the hybridist, though I do not think that a really successful cross has yet been made with it. Anyone who has once felt the attraction of the gladiolus species can never leave them. They are undoubtedly difficult; I was much troubled with a sclerotium disease and used to dip in formalin solution every season, but now I grow them on sandy soil and not on the same ground for more than four or five years, and my bulbs are all perfectly healthy, the only trouble being rodent moles, for which there seems to be no cure but only one long unceasing fight.

The big torch-lilies (Kniphofia Zululandiae) near the waterfall are making a brilliant flame of colour among the ferns and tall grasses of the streamside. These are the biggest and most fiery that I have seen. There is a so-called hybrid grown in England which looks much the same: the stem is five to six feet tall and the flowers about two feet of it. They make one remember the glow from a blacksmith's forge on a late November afternoon in England. When cut they look majestic with Strelitzia reginae, which is blooming quite close to them. I first saw this plant in the public gardens in Conoor, Madras, and could hardly believe it to be a flower; I little thought that I should ever see it in bloom in a garden of my own. There is nothing of the get-rich-quick about them for the nurseryman. To begin with, they often take a year to germinate, though they will sometimes make an appearance at three months if the seeds are well soaked before sowing. They then make 
nice solid little plants, and so they remain for another summer. The following season they make one leaf-and so they go on. They require good rich soil and plenty of water in summer. Probably where summer rainfall is the rule they progress more quickly ; at any rate, if one does persevere there is a big reward ; my plants raised from seed now give me magnificent blooms nearly all the year round.

Strelitzia augusta grows far more quickly and to a far greater size, but I do not like it. There is too much leaf in comparison with the flowers, which are white and blue. The whole plant very much resembles a banana tree, and visitors to my garden often insist that it is one.

Strelitzia parvifolia var. juncea is aptly described by its name. It is neat, decorative, and the flowers are just like those of S. reginae. 
A BITINGLY cold day after fierce rain storms; but what matter since we are off for L'Agulhas? The Robinsons picked me up in Stellenbosch, and in wind and rain but full of faith we set forth on our 150-mile journey, using the precious petrol carefully saved for the purpose.

When we were over the first range of mountains there was a gleam of sun; and as we went on the weather definitely cleared and our faith was justified. The car was full to capacity, a passenger to Bredasdorp and stores for the house at L'Agulhas, hats, cakes, boxes of eggs, two dogs and a pumpkin getting jolted together, but we arrived well before dark and dug ourselves in while the sun set behind the cliffs and the lighthouse took over.

$A$ glorious feeling to be on the end of a continent, knowing the thousands of miles behind us to the north! Here the sea comes rolling in, and one walks over short springy turf to the shore. It might well be Dunwich, for here, too, the sun rises over the sea, in the morning all is gay and sparkling, and at evening there is the everlasting sadness of the sea. Peewits fly over or run daintily on the grass searching for grubs as they did at Easton Broad-only here they call them keweetjies. The duikers fish from the rocks, and we see an occasional kingfisher, a big fellow in black and white.

The rock pools at low tide are all joy. The colours tell of a different world, something outside our ken, such strange greens and a lovely mauve that is almost pink, and then as one watches the shells begin to walk about, curious creatures shuffle sideways across the floor, sea anemones wave maroon-coloured tentacles, and it is like the children's fairy tale where the toys come alive at midnight.

Along the shore, growing among the short grass and bushes, are lachenalias and freesias, not in bloom yet. When I was here in March, L. rubida was in full flower. Now I see L. pendula has come through. There are even some tight buds showing, and it will bloom here about the end of July or early August. 
This is one of the best-tall stems with deep red bells tipped with green; it has been cultivated in Europe for many years.

Climbing the slopes, I found an Adenandra new to me, a little dwarf Sutera and Protea Susannae in flower. In August and September the whole place will be starred with blossom of every kind. I took home plants of a Salvia said to have brown flowers, a little dwarf statice, and seeds of a charming bush with green flowers near to the protea family. Curiously enough it grew with the lovely green-flowered heath, but there was no seed on that yet. As we came back from a tramp one evening with high cliffs on our right hand and the sea on our left, the sun was setting behind the cliffs, making a clear silhouette of the bushes growing on their edge. We were watching this effect when one of the bushes distinctly moved; and as we gazed we realized that the bush was a large buck. We saw one after another of these most decorative creatures emerge from a kloof and group themselves on the sky-line, making a very charming outline. We were so far below that we were of no interest to them whatever.

On the way back from L'Agulhas we found the first freesia in bloom, a small one with leaves like fingers flat on the ground, and blooms cream deeply blotched with orange. We felt that spring could not be very far away. 
BACK HOME again to find the garden drenched and everything sodden. The air seemed raw and cold in the mountains after the soft airs and pleasant sunshine of L'Agulhas. However, a glorious patch of Homoglossum Salteri in my bulb garden soon cheered me. They have the appearance of being extremely delicate; the thin stems, fine as wire, are about $1 \frac{1}{2}$ feet., the blossoms a true scarlet with biscuit-coloured markings on the lower lip and inside the throat. Yet they stand up to the buffetings of gales, and days and days of lashing rain, and then with the first gleam of sun they are resplendent and remain in bloom for a month. They are popularly known as "flames", and the name suits them well. To anyone but a botanist they would be a species of gladiolus; the ordinary grower does not observe the cylindrical shape of the tube which makes all the difference. It would be interesting to try to cross them with a gladiolus, but there are none in bloom now.

Homoglossum merianellum is perhaps even more brilliant, the scarlet of its blooms a shade brighter and the inside of the lip and throat like the yellow glow of a flame. Unfortunately they do not take kindly to cultivation. I have a few; but they do not increase and set very little seed. In their native haunts among the rocky slopes near the sea in the neighbourhood of Cape Point they are a lovely sight.

Another beautiful species is Homoglossum Watsonium; this grows on the higher mountains, and is somewhat more robust and even more like a gladiolus. Again I have not found it easy to cultivate. 


\section{TH JULY.}

WEEKS OF continuous rain, deluging storms, rain dripping through the roof, rain standing in pools even in my hillside garden, streams crashing in silver cascades down the mountain slopes, and everywhere the sound of running water. Now to-day comes suddenly the knowledge that spring has begun.

Yesterday I heard a new bird-note from a warbler by the stream. To-day the doves are more than usually insistent; many of the plants show signs of new growth and flower budslittle indeed to distinguish a change in season and yet enough to start the thrill that comes every year, a call that finds an unfailing response however old we are. There will be rain and storms for months yet; but what matters it? The surge of life is upward again; the resurrection is enacted before our eyes ; beauty makes ready; the orchestra tunes its instruments. We can afford to wait a little.

For three weeks I have been cutting lachenalia flowers, first Lachenalia Roodiae, a good lilac-purple which always comes first, then the beautiful $L$. pendula with its very large pendulous red blooms tipped with dark green or black, then L. tricolor in red, green and orange, whose clear colours have a very gay effect. But the best lachenalia that I have is one that came from Australia as L. Pearsonii, though I think it is not a true species and should guess that it is a hybrid between $L$. aurea and $L$. tricolor. I do not know who raised it. It is very tall with blooms bigger than $L$. pendula, colour a deep orange shading into red. These colours blend giving a bronze effect, and both the stems and the leaves are heavily spotted. It has a long blooming season, and is very popular with the florists; but it sets very little seed. I have heard a rumour of a beautiful scented lachenalia to be found in Namaqualand, but so far I have not seen it, though I am still hoping. I believe it does not take kindly to our wet winters.

The earliest of the fine-leaved gladioli are beginning to bloom, and their scent on warm days hangs over the bulb beds. Gladiolus gracilis enchants us every year with its delicate flowers, a lovely shade of grey-blue on such very fine stems, and now the yellow blooms of $G$. carinatus var. are making a gay patch. 
But the high-light of the bulb beds now is Romulea sabulosa. Every year I marvel at it afresh-such a tiny plant with such a big bloom; and the colour! I have no idea how to describe the colour-neither pink nor red, rose nor cerise, gives any idea of it, and the texture is such that light appears to shimmer over it, to be reflected from its gleaming surface. It is one of nature's most personal gifts-just to have seen it adds to one's stature.

In the kloof garden there are great glowing spikes of aloes, dozens and dozens of them, and the brilliant green and blue malachite sugar-birds are busy sucking the honey, incidentally making a gorgeous colour contrast.

The first blooms of Protea cynaroides are out. The heads are about 1 foot across the outside, bracts a lovely rose-pink and the centres filled with lemon yellow florets. The seeds of them sown in April are just coming through, but very slowly; how eagerly I watch the seed beds for them and for Leucospermum reflexum ! Such a waiting list for plants, and such poor germination: such are the trials of the nurseryman! 
UGUST is here with weather in samples. Some days we battle with raging south-easters (much too early for these, we say); then, before we realize the change, the wind comes roaring in from the north-west, and rain and hail are crashing down. Then a sudden smile : the sun is shining, the flowers opep, and we feel things are almost too good to be true. And so they are. For one half-hour the rain-daisies (Dimorphotheca pluwialis) are a sheet of glistening white in the blazing sun, and the next they are almost invisible as the rain-clouds sweep over.

But through everything we have the feeling that time is short and we simply must get on. Our inescapable duty is to prepare for all the beauty that is about to be displayed, and to give it a suitable setting. If we do not make ready at once, it will be quite too late and another opportunity will be lost, for

When the hounds of spring are on winter's traces,

The mother of months in meadow or plain

Fills the shadows and windy places

With lisp of leaves and ripple of rain.

The new nursery is taking shape, the contour ploughing has been done and the contour banks are to be permanently planted with showy proteas and leucospermums, having as a ground cover all the best of the Arctotis species and hybrids. So we hope to avoid the ugly gashes on the hillside slopes, gashes that are all too apparent on the neighbouring lands. The bulbs have shown their appreciation of a remove to new soil. Romulea, Sparaxis and Gladiolus species have flowers very much larger than I have ever seen anywhere. The ground was well manured the year before we took it over, and we gave heavy dressings of home-made compost which seems to suit them better than anything.

The great thrill is the appearance of the wild flowers in the parts of the farm that have never been cultivated-also around the fences and along the old dongas. First we had Gladiolus gracilis (blue pypie), and then big groups of the dainty 
little Hypoxis stellata, var. elegans, whose gleaming white stars show peacock patterns in the centre. Now there are butterfly moreas (Moraea papilio), six inches high, in shades of salmonpink, terra-cotta and lemon. There are sundews with big lilaccoloured blooms and blue lachenalias (L. unifolia) under the oak trees; but the best find of all was Cleanthe bicolor (now classed as Aristea), growing in big clumps and just opening its pale blue flowers enough to show the heavy black centres. I had this plant years ago and lost it. It is somewhat temperamental, and my garden is too wet for it. Now I hope to collect seeds and start again. A big patch of Monsonia flowers were out before the ones I have growing in the garden, and now the kalkoentjies (Gladiolus alatus) are popping up here and there. This district used to have them in quantities along the roadsides in the corners of orchards and vineyards, and where the veld was still untouched. But the plough, veld fires, erosion in the winter storms, and wholesale picking for sale have done their worst; and now the kalkoentjie is seldom seen. Surely man is the most destructive animal on earth, and destroyers are so many and preservers so few.

And now we realize that the year has come full cycle. Every spring the feeling of urgency and expectancy is there, and we stand awaiting the opening of the gate into fairyland. Anything may happen, any treasure turn up. Let us forget the storms and troubles-

For winter's rains and ruins are over And all the season of snows and sins, ... And frosts are slain and flowers begotten, And in green underwood and cover Blossom by blossom the spring begins. 


\section{CULTIVATION OF BULBOUS PLANTS.}

I MUST explain that I use the term " bulbous" in the nurseryman's manner of speaking. I know that botanically most of the plants mentioned below have corms, some of them bulbs, and a few grow from tubers.

I consider that where the plants are to be grown in the northern hemisphere much better results are to be obtained by starting from seed. Nearly all the seed germinates very readily, and the general rule is that some (such as Sparaxis, Freesia, Streptanthera) are in bloom the second season and all will be flowering well the third spring after sowing. Here we sow our seed with the earliest rain in April (autumn), or if we have only a small quantity to sow and they can be kept shaded and watered they are better sown in March. The aim is to get as long a growing season as possible for the seedlings, for as soon as the sun grows hot in early summer they will begin to die down and will remain dormant until autumn rains come again.

Where there is rain in summer, the seedlings must be protected from it, as it is absolutely necessary for them to dry off and have a complete rest. I think they are better if left undisturbed their first season. They will come up when rain or watering starts again; and if the soil contains plenty of compost it will not need replenishing until they die down for the second time. This time the bulbs should be taken up. They are now quite dormant and may be planted out immediately or kept for a few weeks in store.

With regard to the soil, any good garden soil is suitable so long as it is light and friable. Good drainage is essential, and full sunshine. Most of the Cape bulbs come from the Western Province, where the soil is definitely acid. There are very few that can stand up to lime; and of course new manure cannot be tolerated. I find that compost suits them better than any fertilizer; and since I have used only this I have had no disease. There are a few that require special treatment. Lachenalias do better here in semi-shade, especially the late-flowering 
species such as L. glaucina. Gladiolus grandis (big brown Afrikander) has flowers too delicate for full sunshine: in its nat ve haunts it grows among rough grasses and bushes.

Now for the bulbs that like to grow in summer and to go dormant in winter. These come either from the Eastern Province of the Cape, where rain may come at any time, or from farther north where the rains come in summer and the winters are cold and dry.

Gladiolus Stanfordiae should never dry out. Of the nerines only N. sarniensis likes to be dry in summer (and it must have a thorough baking before flowering). The form of Brunsvigia gigantea that grows at the Cape dries off in summer, whereas those from "up country" are like B. banksiana in that they flower in summer.

The haemanthus species present the same problems. Haemantbus coccineus likes to do its growing in the wet Cape winters; but most of the others like to grow in shade, getting water in summer and flowering with their leaves. All species of Haemantbus like good rich soil with plenty of leaf-mould and compost, whereas if nerines are overfed they produce nothing but leaves. They should be left undisturbed until they literally burst out of their containers. The blooms improve every year, and they respond to an application of liquid manure just before flowering. When the leaves are growing, they are then building up next season's flowers. Among the species of Cyrtanthus, some require water all the year round. Among these are Cyrtanthus Mackennii, C. O'Brienii, C. lutescens and their hybrids. Most of the species grow in summer and like to get water then and to be dry in winter. C. obliquus, C. Tuckii and C. sanguineus belong to this group.

I think that failure to observe the correct dormant season is the chief cause of failure in growing South African bulbs; but there is another snag for beginners. When such things as Gladiolus tristis, Moraea villosa or Romulea sabulosa germinate, they can hardly be distinguished from the fine grass which so persistently comes up in our seed boxes; and many of the prized seedlings have been pulled out as such. Also when the seedlings begin to turn brown and eventually die down the 
beginner wonders what he had done wrong, thinks they are all dead, and casts them away in disgust.

This misfortune has also happened to seedling pelargoniums. Some species have learnt the habit of storing up their life-force through the blazing hot summers and almost desert conditions of the north-west Cape, by forming either spiny succulent stems, or corms, or tubers; and when they go to rest they appear to be completely dead. But as soon as the weather is cooler and the rains come their leaves re-appear and they start into growth all over again.

Seeds of the bulbous plants which grow in summer should be sown in spring. Among these are Galtonia candicans, Ornithogalum Saundersiae, Gladiolus crassifolius, G. salmoneus and $G$. psittacinus. Also all gloriosas, yellow and pink arums, Schizostylis, and Haemantbus, Streliţia, Vallotta and Eucomis.

Such seeds as Nerine, Crinum, Brunsvigia and Clivia should be sown just as soon as they are ripe. Some will even begin tn germinate while thev are still on the plant.

Such things as Agapanthus and Kniphofia germinate at almost any time when conditions are not too severe (i.e., when neither too hot nor too cold). Although seeds of nearly all bulb plants germinate well, they are never in a hurry. Most of them take a month before the seedlings appear; and occasionally a proportion of the seeds will germinate in the usual time and the rest will lie dormant to appear the following season.

It must be remembered that Cape plants do not require tropical conditions. Most of our bulbs that I have seen grown in England struck me as being kept too hot and too wet. The condition to be aimed at should be plenty of air, plenty of sun, plenty of water when growing, and absolute dryness when resting. 


\section{CULTIVATION OF COMPOSITES.}

MOST OF the annuals are best sown where they are to flower. Where winters are mild, they may be sown in autumn and will flower early spring; but if frost is expected they should be sown in spring. Some of them will stand transplanting if it is done carefully and quickly, but mostly they should be thinned out. They flower best in full sun in soil that is not too rich.

Perennial dimorphothecas and gazanias we sow in early autumn and plant out as soon as big enough ready for spring flowering ; but in colder climates they must be sown in spring and then brought through the winter in a cold frame or slightly heated greenhouse.

Dimorphotheca spectabilis is always best sown in spring. Care should be taken to cover seeds of all these plants very lightly when sowing. 


\section{CULTIVATION OF PRO'TEAS.}

MOS'T OF us are ready to acknowledge that we know very little on this subject. Sometimes our successes surprise us as much as our failures. The seeds of most proteas and leucospermums germinate in erratic fashion. I sow them in early autumn in the open ground, and they continue to germinate for six months. Indeed, it is more than likely that they will go on, appearing in a year's time. Some seeds of a sowing of Leucadendron argenteum (Silver Tree) made their appearance five years after sowing. The seedlings must be transplanted into permanent quarters while they are still very small. Though there may be only one pair of leaves on the tiny plant, the root is already six inches or more in length ; and if the tip is damaged the plant instantly dies. So it is clear that the seedlings need very careful handling. When planting, it is essential that a deep hole be prepared and filled with loose soil. If in a few years' time the roots come in contact with rock or clay, the plant will not survive. I use compost for mixing with the soil: lime is to be avoided. Later on care must be taken when cleaning round the bushes not to disturb the fine roots growing near the surface: this is often a cause of sudden death. All proteas should be planted on sunny well-drained slopes in full sun. The seedlings may require water the first summer. 



\section{INDEX OF GENERA}

Adenandra, 51

Agapanthus, 28, 38, 59

Aitonia, 12, 31, 33

Aloe, 40, 47

Alstroemeria, 31

Amaryllis, 2, 23, 29, 39

Antbolyza, 29

Arctotis, 7, 8, 45, 55

Aristea, 17, 56

Arum, 59

Auricula, 2

Babiana, 29

Barleria, 47

Baubinia, 31, 33, 36, 38

Bolusantbus, 27

Brunsvigia, 23, 39, 58, 59

Buphane, 39

Carpobrotus, 9

Catalpa, 28, 38

Cepbalophyllum, 9

Cleanthe, 56

Clivia, 59

Cotyledon, 20, 21, 22

Crinum, 14, 23, 59

Cyrtanthus, 47, 58

Dierama, 17, 32

Dimorphotheca, x, 5, 6, 17, 24, 55, 60

Dipidaxtriquetra, 14

Dorotbeanus, 9

Drosanthemum, 9, 20

Erythrina, 14, 31, 33

Eucomis, 59

Felicia, 17, 45

Freesia, 3, 11, 50, 57

Galtonia, 59

Gazania, 15, 16, 17, 45, 60

Geissorbiza, 3

Geranium, 24

Gerbera, 27, 33, 35

Gladiolus, 2, 3, 10, 11, 17, 30, 37, 45, 46, $47,53,55,56,58,59$

Gloriosa, 31, 59

Habrantbus, 31

Haemantbus, 31, 37, 39, 43, 58, 59

Helicbrysum, 22

Heliopbila, 8, 21
Hesperaloe, 28

Hesperantba, 2

Hibiscus, 29

Homeria, 3

Homoglossum, 52

Hydrangea, 29

Hypoxis, 56

Ixia, 11, 17, 19, 30

Jacaranda, 29

Jasminum, 32

Kniphofia, 15, 31, 33, 34, 48, 59

Lachenalia, 1, 3, 11, 45, 50, 53, 56, 57, 58

Lamprantbus, 8

Lapeyrousia, 3

Leucadendron, 33, 61

Leucospermum, 5, 11, 19, 33, 34, 36, 42, 54

Liparia, 42

Lobostemon, 27, 43

Mesembrianthemum, 8.9

Monsonia, 56

Moraea, 1, 56, 58

Nerine, 32, 47, 58, 59

Nymania, 12

Ornithogalum, 19, 31, 59

Pelargonium, 12, 20, 23, 24, 59

Plumbago, 47

Podalyria, 10

Portulaca, 9

Protea, 5, 11, 12, 42, 43, 45, 51, 54, 61

Romneya, 29

Romulea, 54, 55, 58

Salvia, 51

Schizostylis, 59

Sclerotium, 11

Senecio, 17

Sparaxis, 2. $11,29,30,55,57$

Statice, 51

Strelitzia, 48, 49, 59

Streptantbera, 2. 11, 57

Sutera, 51

Vallota, 29, 59

Virgilia, 34

Wachendorfia, 14

Watsonia, 17, 29, 32

Wistaria, 26 


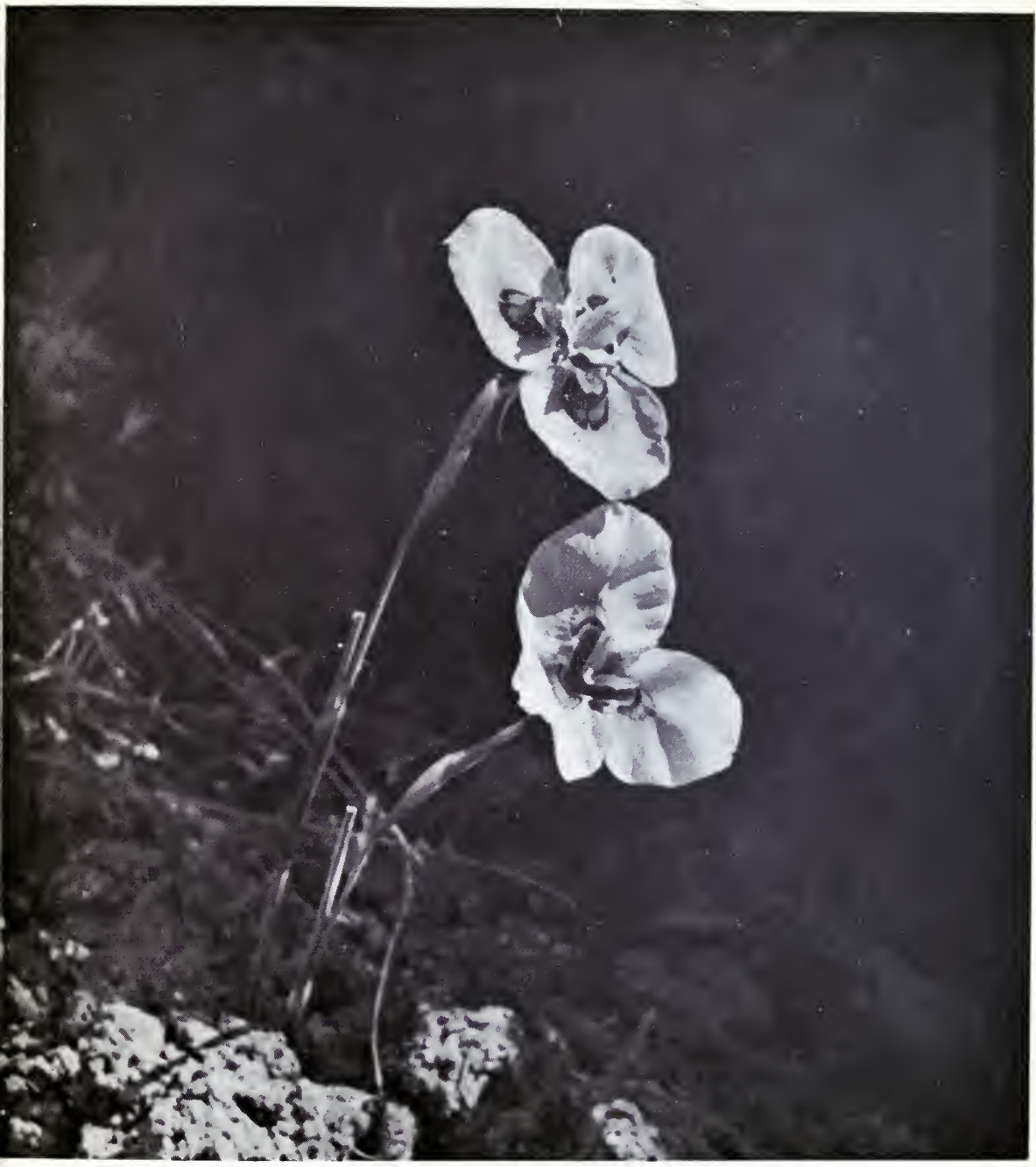

Moraea villosa. 




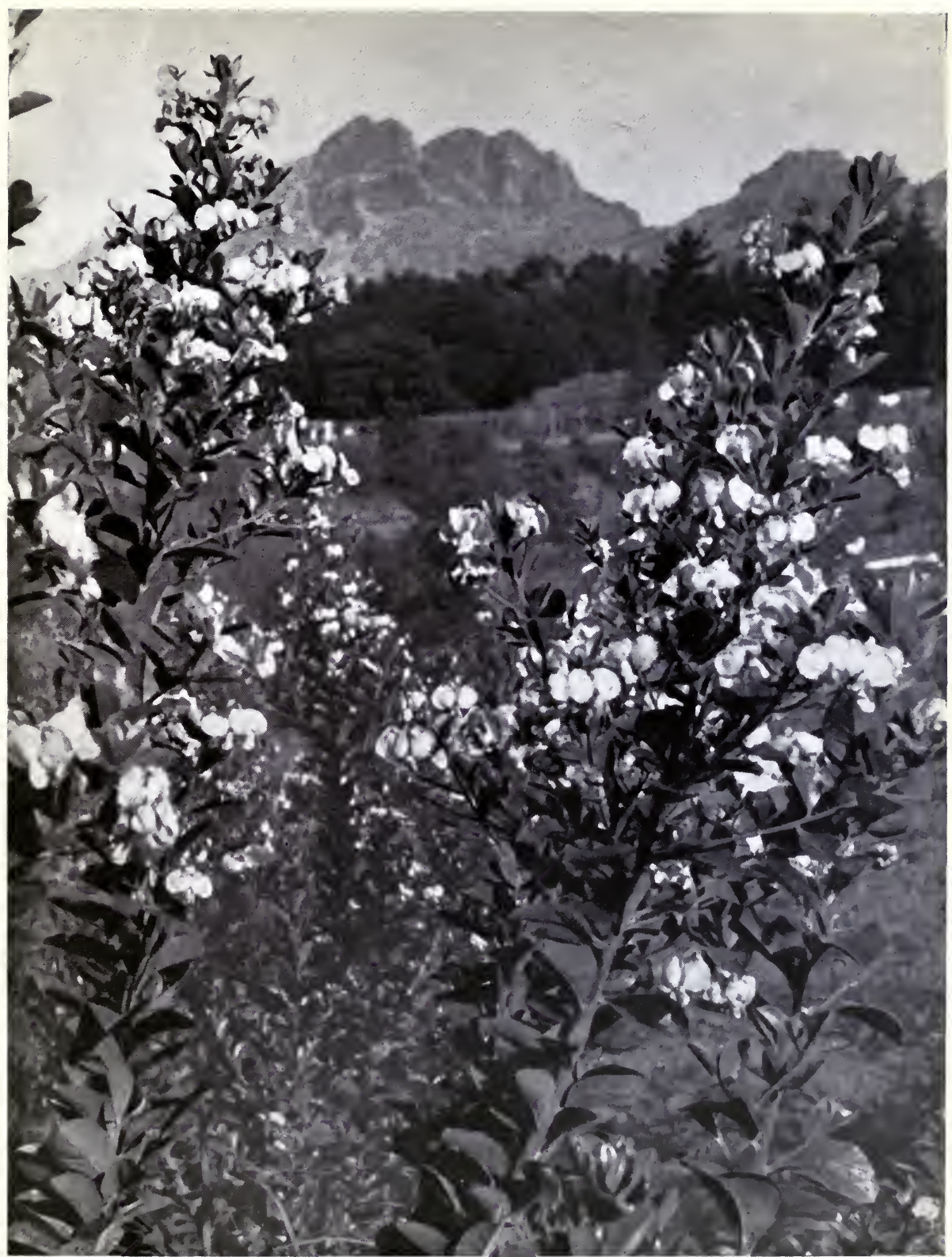





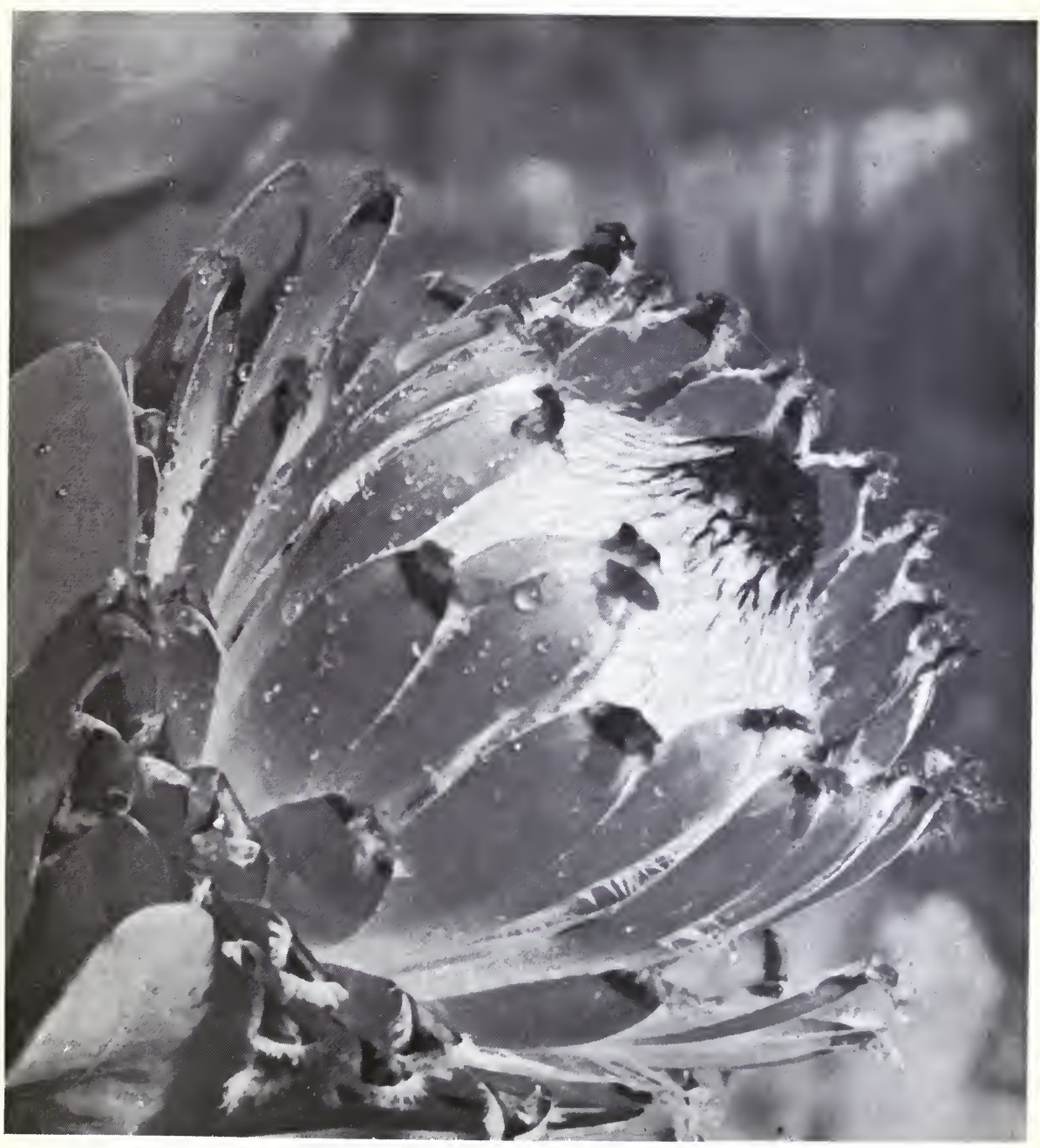

Protea barbigera. 


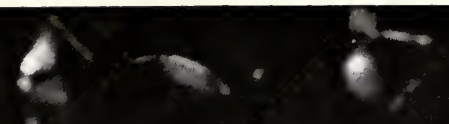

2.

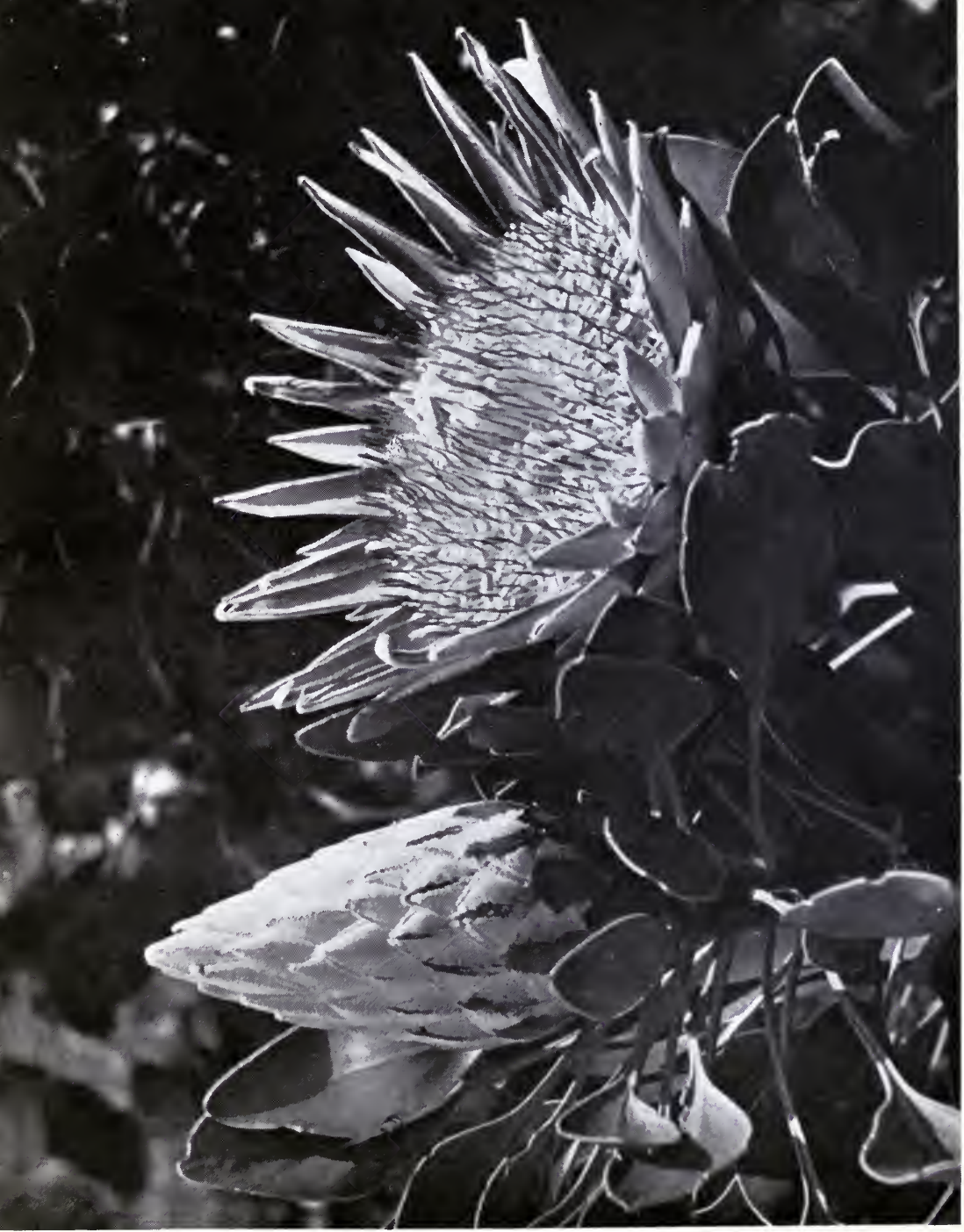




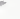




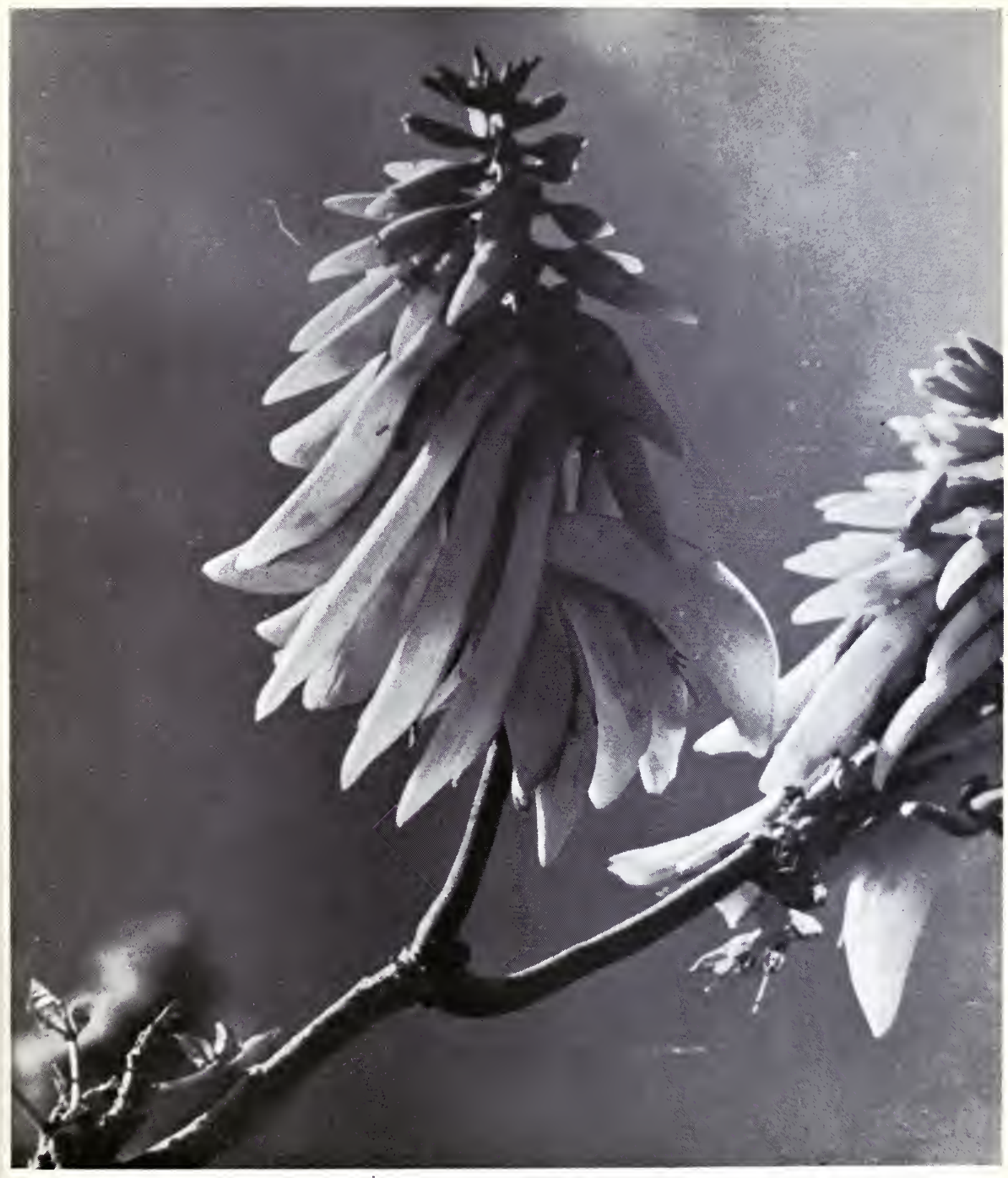

ERYTHRINA (KAFFIR-BOOM). 




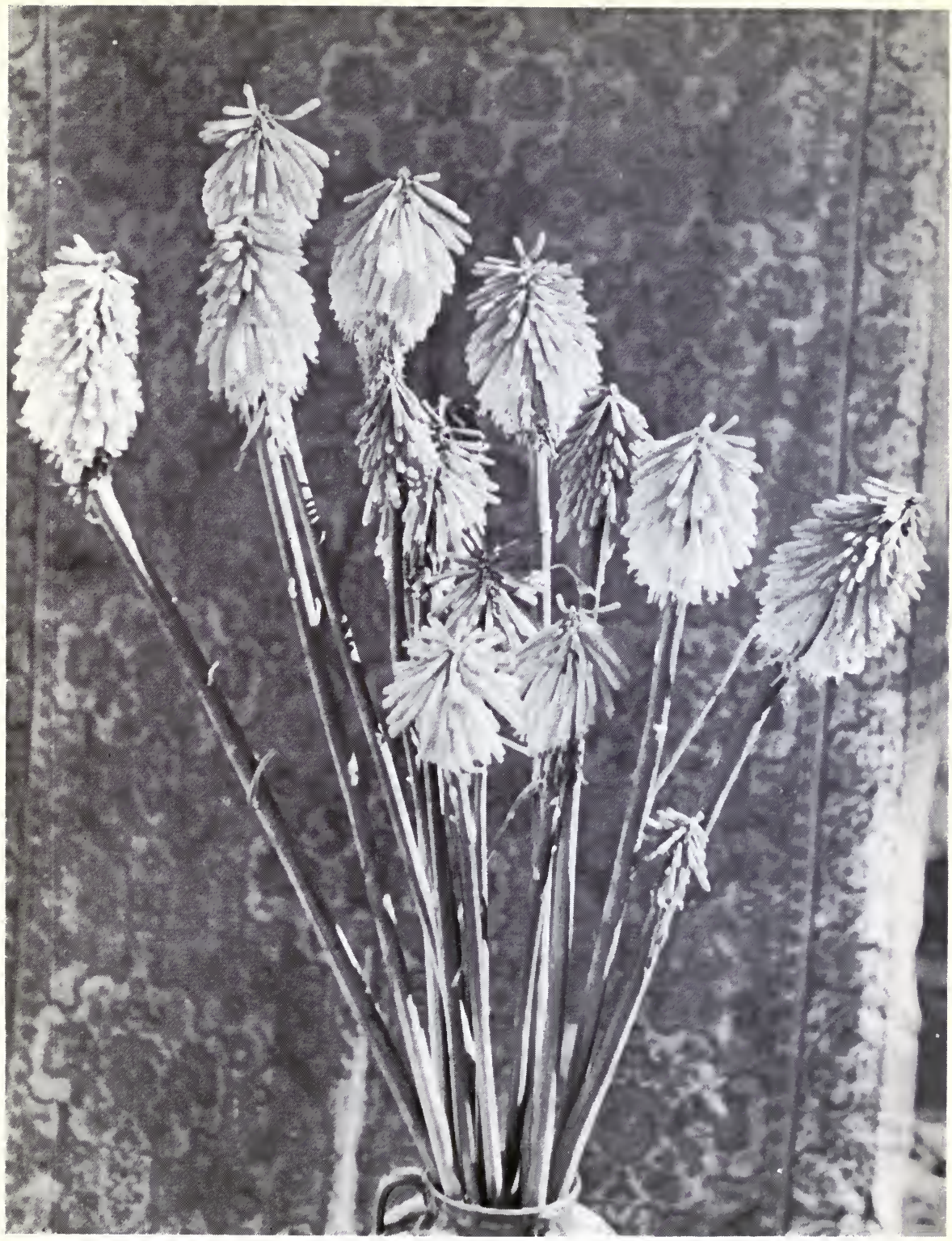





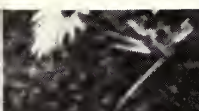

onit gin if ${ }^{3}$ ir ( - Eva

4 in $=03$ I है की

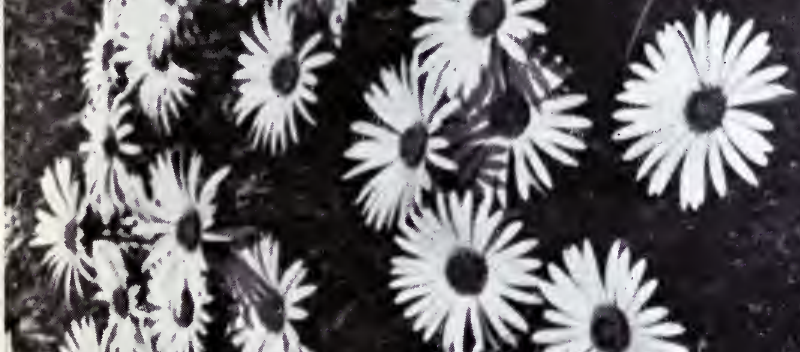

Nyin?

15 of ofy

or 1 -

vente

vald

vente 1. ( n t I.

$74+2=14$

करत

$4 t^{2}=$

- $1 x^{2}(1 / 2)$

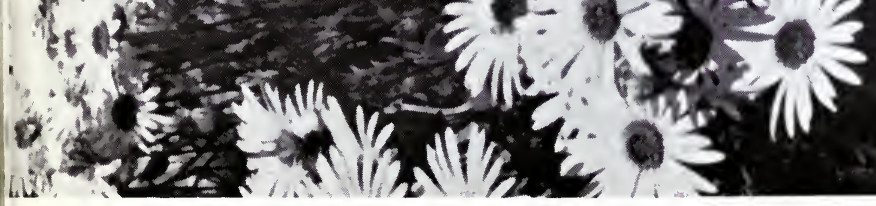

1) $301 / 41 / 5$ 


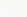




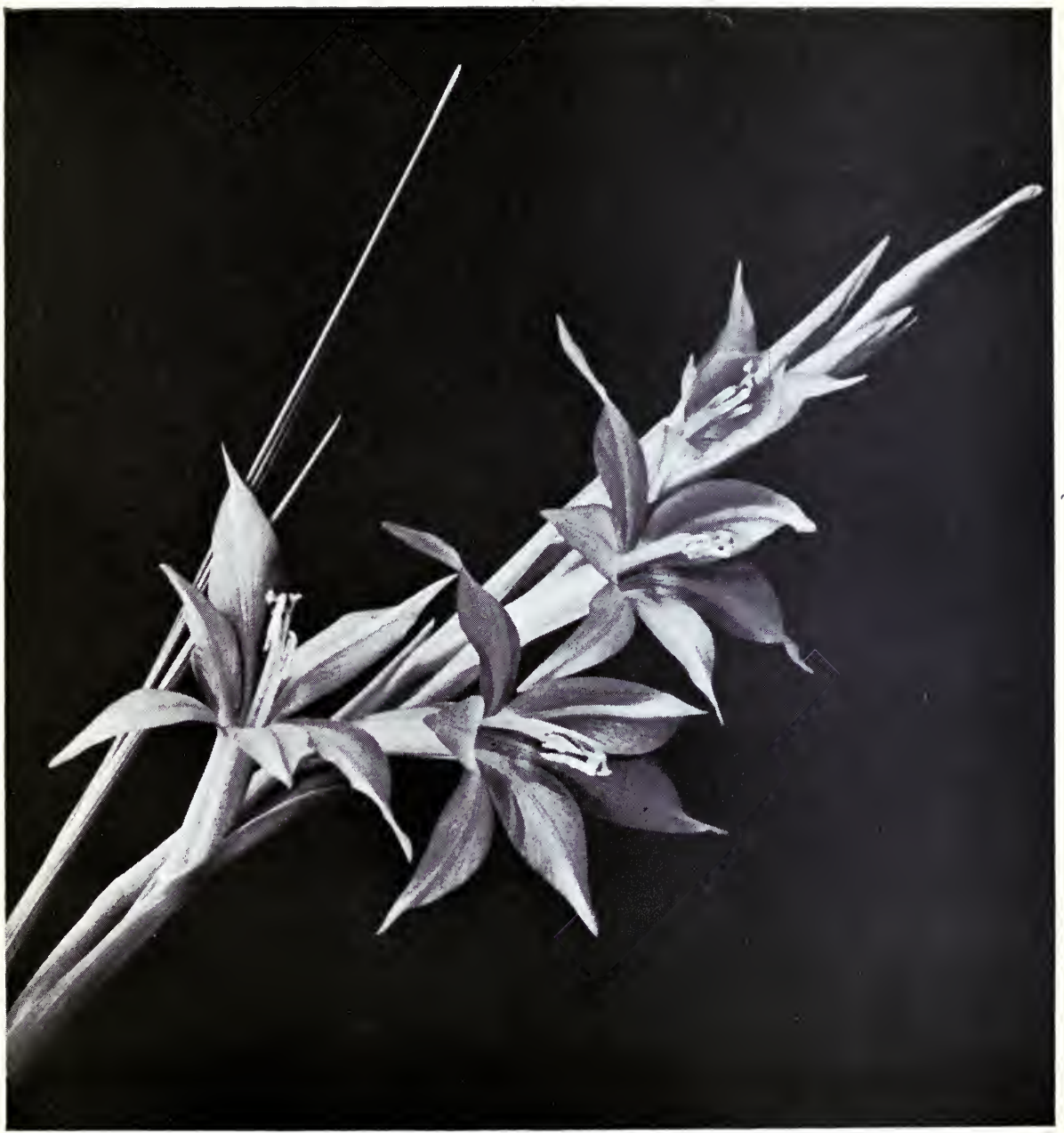

Humoglossum Watsonium (Dig red Afrikander). 




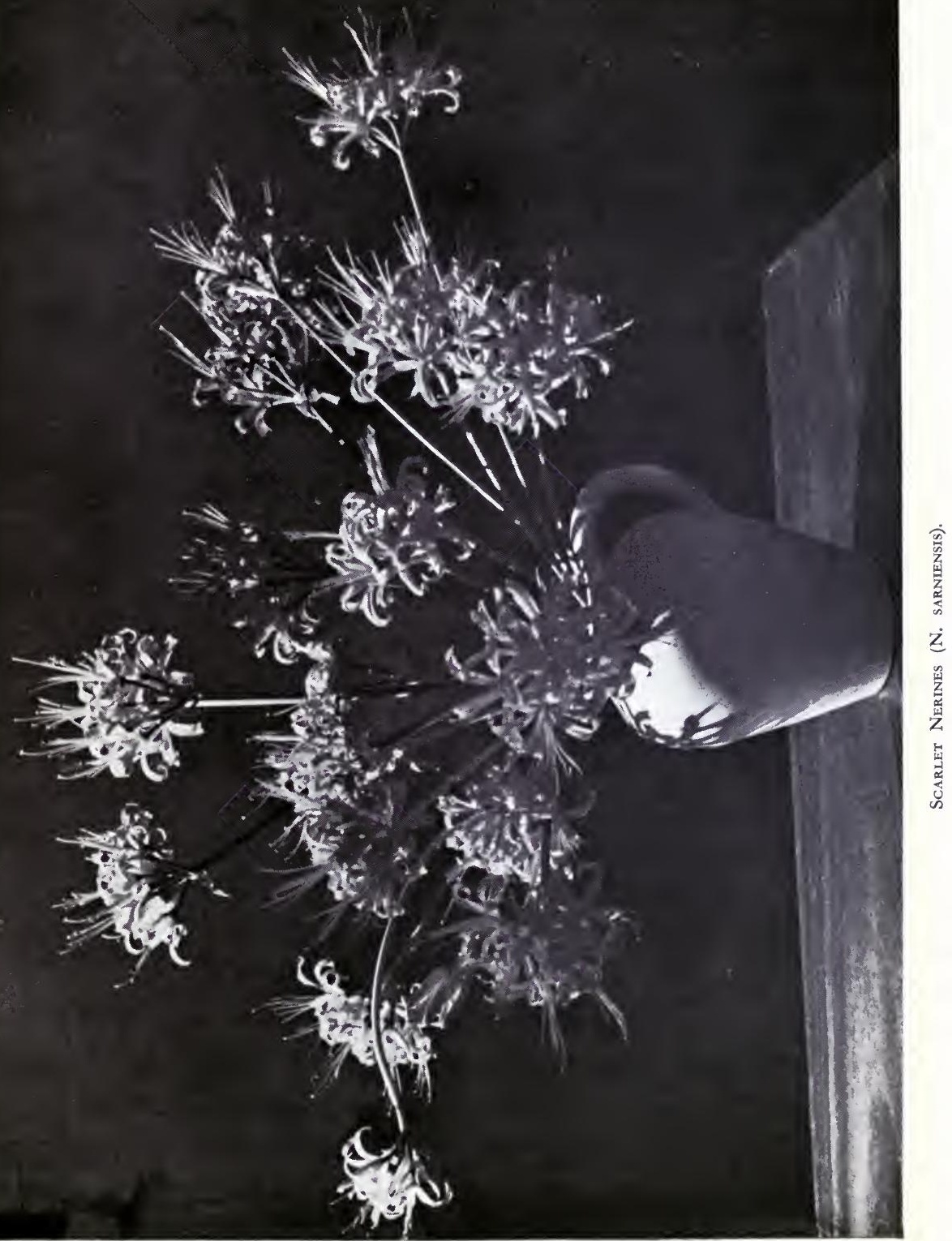


A 
UNIVERSITY OF CALIFORNIA LIBRARY

Los Angeles

This book is DUE on the last date stamped below.

\section{$A B R+1954$ \\ J4L. \& $\$ 2$ ह}

Form L9-10m-1,'52(9291) 444

THE LIBRARY 
UC SOUTHERN REGIONAL LIBRARY FACILITY

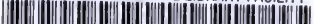

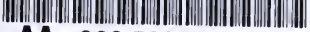

AA $000566763 \quad 9$ 
